\title{
FISH TAXONOMIC AND FUNCTIONAL DIVERSITY IN MESOHABITATS OF THE RIVER KAKADA, CAURA NATIONAL PARK, VENEZUELA
}

\author{
Gabriela Echevarría ${ }^{1}$, Nirson González ${ }^{2}$ \\ ${ }^{1}$ Venezuelan Institute for Scientific Research, Venezuela \\ e-mail:hydropsichidae@gmail.com \\ ${ }^{2}$ La Salle Foundation of Natural Sciences, Venezuela \\ e-mail:nirsongonz@gmail.com
}

Received: 12.04 .2018

\begin{abstract}
The Caura National Park encompasses the entire basin of the River Caura, one of the most biodiverse hydrographic systems of Venezuela, yet the ichthyofauna, particularly in the upper basin, has been poorly studied. In this study, the taxonomic and functional diversity of fishes in mesohabitats of the River Kakada, a main tributary of the upper River Caura in Southern Venezuela, are described. The fishes were sampled in four mesohabitat types with seines during four different occasions, representing the hydrological seasons of rising waters, high waters, falling waters and low waters. Functional diversity indices were calculated based on four traits: size, trophic guild, mouth orientation and body shape. A total of 56 fish species were registered. There were significant differences in species composition of the fish assemblages and their taxonomic diversities among mesohabitats and across hydrological seasons, and the taxonomic and functional diversities were higher in the mesohabitats with presence of riparian forest. However, there were no seasonal variations in functional composition or functional diversities. The rocky substrates had unique assemblages of habitat specialist species with a particular array of traits. On the other hand, the presence of riparian forest and more structurally complex substrates favors the coexistence of a high diversity of fishes with a variety of trait combinations, whereas the seasonal fluctuations in the water level might propitiate stochastic processes of dispersion and colonisation that generate variations in species composition and taxonomic diversity. Considering the spread of artisanal gold mines in the Caura National Park, the results of this investigation might serve as a reference for future studies that assess the impacts of the gold mining activities on the river integrity and their fish communities.
\end{abstract}

Key words: diversity seasonal patterns, fish assemblage structure, fish traits, Guiana Shield, riverine flooded forest

\section{Introduction}

The ichthyofauna of the Guiana Shield is highly diverse, as a result of the presence of dense wet forests, a great variety of aquatic habitats, a complex geological history and a tropical climate (Funk \& Kelloff, 2009). At least 1168 species belonging to 49 families and 15 orders are known, which exhibit physiological, morphological and behavioural adaptations to very particular water conditions (Vari \& Ferraris, 2009). Fish assemblages in forested rivers of the Guiana Shield sustain a high diversity of species, in spite of their sometimes high acidity. In these rivers, the fish taxonomic diversity is influenced by an altitudinal gradient, the current velocity and the substrate type (Cilleros et al., 2017). For instance, at the segment scale, represented by a sequence of pools and rapids, these rivers show a higher fish diversity in mesohabitats where the accumulation of de- tritus and leaf litter is high and with high structural complexity (Machado-Allison et al., 2003), and the species show associations to distinct mesohabitats according to substrate type, the presence of aquatic vegetation and the structure of the riparian forest (Chernoff et al., 2003). In the upper River Caura, the rapids are associated to rather unique fish assemblages (Machado-Allison et al., 2003).

Yet, the spatiotemporal patterns of fish functional diversity in forested rivers of the Guiana Shield have been little explored. The functional facet of fish diversity can reveal the processes that intervene in community assembly, how species adapt to the aquatic ecosystems features and at the same time how they influence the functioning of these ecosystems (Poff, 1997; Thorp et al., 2008; Villéger et al., 2017). Several models that include functional traits have been proposed to explain the organisation of fish communities, such 
as the habitat templet of hydrographic systems (Townsend \& Hildrew, 1994), the landscape filters (Poff, 1997) or the morphometry - transparency piscivory model (Rodríguez \& Lewis Jr., 1997). These models include traits such as life history, trophic group, habitat preference, morphology and predation mode, which are related to different fish functions, such as food acquisition, locomotion and habitat use, but also can intervene in the regulation of trophic webs and ecosystem engineering (Villéger et al., 2017).

The functional diversity of biotic communities can be analysed from different perspectives. Several indices have been formulated, which assess distinct aspects of the functional facet (Mason et al., 2005). The functional richness represents the functional space filled by a community, whereas the functional evenness indicates how regularly the species fill such space whereas the functional divergence how the abundances of the species are distributed within the functional space (Villéger et al., 2008). This information can provide an idea of the limits imposed by the environmental conditions to the species distributions and to their traits (Keddy, 1992) and also of how the species respond to interspecific competition (Abrams, 1983). These and other indices can be applied to assess the communities responses to disturbances of varied origins (Mouillot et al., 2013), which represents a great opportunity to evaluate the effects associated to gold mining, a growing threat for fish communities in the Guiana Shield (Brosse et al., 2011).

In rivers of other biogeographic areas of South America, the riparian forest and the substrate type can determine the functional diversity and composition of fish communities (Teresa \& Casatti, 2012). The structural complexity of the mesohabitats has been associated to high functional diversities, and contrarily, a lower water $\mathrm{pH}$ has been associated to low functional diversities (Rodrigues-Filho et al., 2017). Likewise, the characteristics of rapids, such as rocky substrates and fast currents, are related to fusiform body shapes and large pectoral fins (Ribeiro et al., 2016), whereas complex substrates with small crevices favour the presence of species with slim and elongated bodies (Casatti \& Castro, 2006). At broader spatial scales, the presence of forest cover is positively correlated with certain trophic groups such as herbivores, detritivores and invertivores (Arantes et al., 2018). The temporal dimension has also a considerable effect on the functional diversity of fish communities in freshwater ecosystems. In Neotropical rivers, temporal variations in functional diversity have been related to changes in habitat and food availability (Echevarría et al., 2017), as well as to variations in the intensity of biotic and abiotic mechanisms of community assembly (Fitzgerald et al., 2017) across the hydrological cycle.

In the River Caura Basin, a recently declared national park, the taxonomic diversity of fishes is relatively well known (Chernoff et al., 2003; Machado-Allison et al., 2003; Vispo et al., 2003; González et al., 2012a), as well as some ecological aspects of the fish communities such as their trophic structure (González \& Vispo, 2004) and reproductive biology (Echevarría et al., 2011). The only study of functional diversity was carried out in mesohabitats of two floodplain lakes of the lower River Caura (Echevarría \& González, 2018), where significant spatiotemporal differences in taxonomic and functional diversities were evidenced, with the highest diversities occurring in mesohabitats of leaf litter and sandy bottoms. It was also found that these mesohabitats were associated to different fish traits. For instance, small invertivores were associated to sandy bottoms, and detritivores were associated to mesohabitats with submerged logs. To our knowledge, the present research is the first to encompass the study of functional diversity in a forested river of the upper River Caura Basin.

Despite its protected status, The River Caura Basin is being threatened by the increasing presence of illegal, artisanal gold mines, which are disturbing the natural conditions of the drainage (Chernoff et al., 2003). Additionally, the Venezuelan National Executive approved the exploitation of the mining arch (Presidencia de la República Bolivariana de Venezuela, 2016), which encompasses a significant area of the Venezuelan Guiana Shield and of the basin of the River Caura, to exploit gold, diamonds, coltan and other minerals. This could seriously endanger the fish assemblages in this basin, therefore information about their taxonomic and functional diversity patterns prior to the mining activities are very necessary more than ever.

The main goal of this research was to provide baseline information about the fish communities in the mesohabitats of the River Kakada, as well as a reference for future studies that measure the fish communities' responses to disturbances related to gold mining. The specific objectives of this research were 1) to determine if the taxonomic and functional diversity of the fish assemblages 
varied among mesohabitats and across hydrological seasons; 2) to identify the most taxonomically and functionally diverse mesohabitats and 3) to explore the fish traits - mesohabitats associations. Higher taxonomic and functional diversities were expected in the mesohabitats of littorals with riparian forests and clayey bottoms and littorals with bottoms covered by debris, due to the presence of riparian forest and their higher heterogeneity in comparison to the sandy bottoms and rocky substrates. We also expected to find similar fish trait mesohabitat associations to those observed in the lower River Caura.

\section{Study area}

The study was conducted in the River Kakada, which is a tributary of the River Erebato in the upper River Caura Basin, within the Guiana Shield. The study area is located within the recently created Caura National Park (Presidencia de la República Bolivariana de Venezuela, 2017), which encompasses the entire basin of this river, a total of 7533952 hectares of territory, and is now the largest national park of Venezuela. The area has an annual precipitation of $3253 \mathrm{~mm}$, annual evapotranspiration of 1677 $\mathrm{mm}$, with highly humid weather (Ministerio del Poder Popular para el Ambiente, 2007). The River Kakada has a highly dense and diverse riverine flooded forest, with 48 families and 97 genera of trees, ferns, vines, epiphytes, grasses and herbs (Díaz-Pérez et al., 2012); the most important families are Fabaceae, Chrysobalanaceae, Euphorbiaceae, Sapotaceae, and Melastomataceae. The River Kakada shows high hydrologic variation and its water is slightly acidic, with low conductivities and alkalinities, corresponding to a rain-dominated system (Riseng \& Sparks, 2003). In the upper River Caura Basin 172 fish species have been registered so far (González et al., 2012a). The River Kakada is among the most diverse in fishes of the upper River Caura Basin, with several genera and species typical for the Guianese fauna (Machado-Allison et al., 2003). The sampled segment of the River Kakada was located between the co-ordinates $05^{\circ} 31^{\prime} 27^{\prime \prime} \mathrm{N}$ - 64 $36^{\circ} 19^{\prime \prime} \mathrm{W}$ and $05^{\circ} 25^{\prime} 00^{\prime \prime} \mathrm{N}-64^{\circ} 29^{\prime} 40^{\prime \prime} \mathrm{W}$ (Fig. 1a), between 259-300 $\mathrm{m}$ a.s.1. The water depth fluctuated across hydrological seasons, with the lowest average depth $=3.08 \mathrm{~m}$ during low waters to the highest level $=4.5 \mathrm{~m}$ during high waters (Fig. 1b).

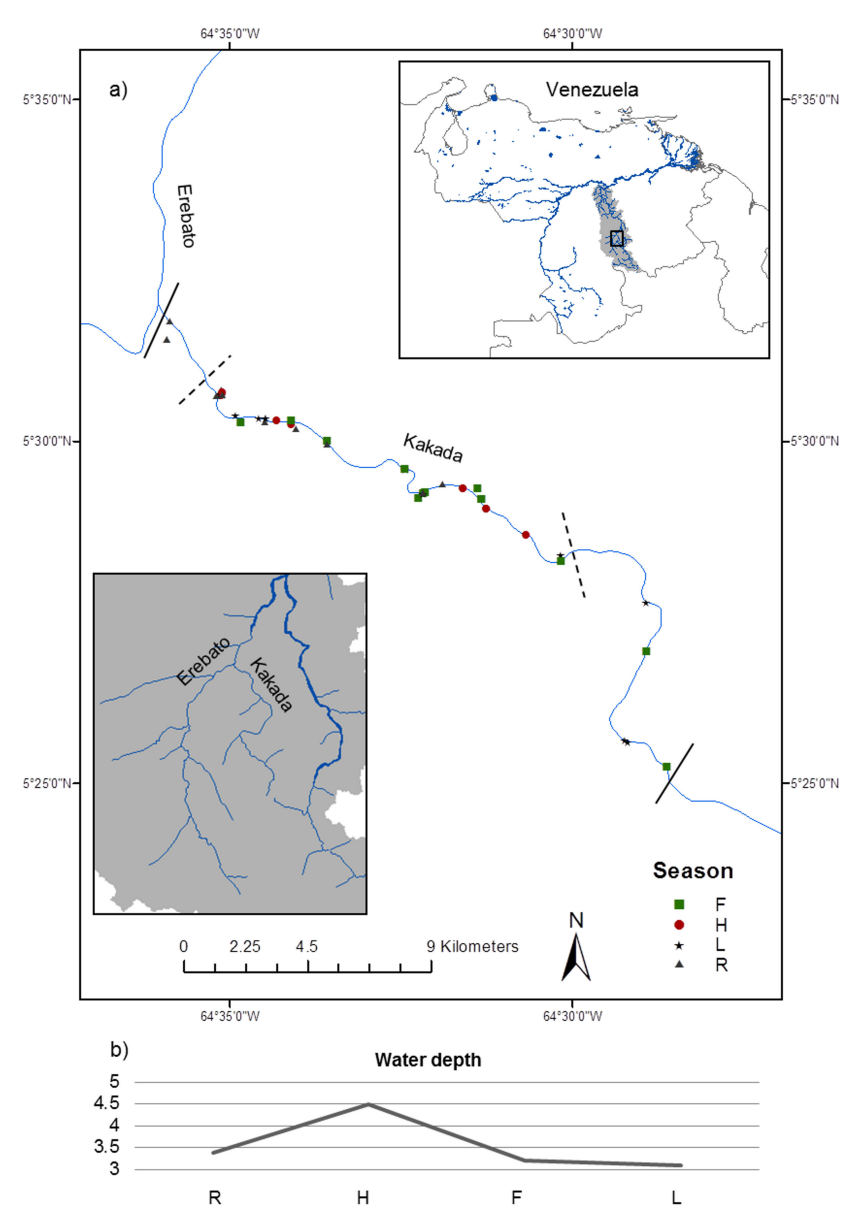

Fig. 1. a) Sampling stations within the River Kakada and location of the study area in relation to the River Caura Basin within Venezuela. Solid black lines indicate the limits of the entire sampled segment, dashed lines indicate the limits of the segment subsample. b) The average water depth in the River Kakada during the four sampled hydrological seasons. Season codes in Table 1.

\section{Samplings}

Fishes were collected by daytime seining ( $4 \mathrm{~m}$ $\times 1.5 \mathrm{~m}, 0.5 \mathrm{~cm}$ mesh) from 2008 to 2009 covering the four seasons of a hydrological cycle: rising waters in May 2008, high waters in September 2008, falling waters in November 2008 and low waters in April 2009. During each season, from 12 to 14 sites were sampled in the channel of the River Kakada, encompassing different mesohabitats (Table 1, Fig. 2a) within a $25 \mathrm{~km}$ segment of the river. Sampling sites were chosen if they had at least $10 \mathrm{~m}$ through which the seine could be hauled. At each site, the seine was hauled three times through an approximate distance of ten meters, with water depths ranging from 0.5 $\mathrm{m}$ to $1.5 \mathrm{~m}$. The average distance between sampling sites ranged from $1.46 \mathrm{~km}$ during low waters to 1.83 $\mathrm{km}$ during rising waters, with an average distance of $1.67 \mathrm{~km}$ during falling waters and $1.68 \mathrm{~km}$ during high waters. The habitats were characterised by a visual inspection, according to the area covered by each type of substrate $(>50 \%)$. All collected individuals 
were fixed in formalin at $10 \%$, and later transported to the laboratory of Fish Ecology of Fundación La Salle de Ciencias Naturales, Campus Guayana, where they were identified to the species level when possible (Géry, 1977; Nijssen \& Isbrücker, 1982; Vari, 1983, 1989; Kullander et al., 1992; Taphorn, 1992; Mago-Leccia, 1994; Machado-Allison et al., 1989, 1996; Lasso \& Provenzano, 1997; Chernoff \& Machado-Allison, 1999; Lasso \& Machado-Allison, 2000; Armbruster, 2002; Chernoff et al., 2002; Willink et al., 2003; López-Fernández et al., 2006; Oyakawa \& Mattox, 2009; Vari \& Ferraris, 2013), and finally deposited in the Ichthyological Collection of the Estación de Investigaciones Hidrobiológicas de Guayana (CRI-EDHIG) belonging to the Fundación La Salle de Ciencias Naturales, Campus Guayana.

\section{Fish traits}

Four traits were selected, two of them related to habitat use: standard length and body shape (Winemiller, 1991), one representative of resource use: trophic guild (Mason et al., 2008) and one related to mode of food acquisition: mouth position (Winemiller, 1991). The standard length was measured with a caliper and the average per species was used. The body shape and mouth position were established from field observation of the specimens and the trophic guild was determined through inspection of gut contents, from published literature (González \& Vispo, 2004; González et al., 2012b) and from Fishbase (Froese \& Pauly, 2018).

\section{Statistical analyses}

The comparisons of compositions of fish species among mesohabitats and hydrological seasons were made with non-metric multidi- mensional scaling (NMDS) and PERMANOVAs (Anderson, 2001) based on Bray - Curtis distances obtained from the abundances of fish species in each sample. The significance of the test was obtained through 999 permutations. The permutation of residuals method was applied under a reduced model, recommended for designs with more than one factor (Clarke \& Gorley, 2006). The design consisted of two factors: mesohabitat and season, both fixed factors, as recommended by Anderson et al. (2008) for comparisons of repeated measures. Previously, an analysis of multivariate homogeneity of group dispersions was carried out to check the heterogeneity of within-group dispersions among mesohabitats and seasons. The functional composition of each sample was determined by using community-level weighted means of the standard lengths and the dominant trophic guild, body shape and mouth position in each sample, with the function functcomp() of the FD package (Laliberté et al., 2014) for the R language (R Development Core Team, 2012). With these data a matrix of Gower distances among samples was prepared and then a NMDS ordination and PERMANOVA analyses were carried out with the same design and factors as in the species-based analyses. Additional comparisons of taxonomic and functional composition were carried out that included only those sites between $5^{\circ} 30^{\prime} 32.4^{\prime \prime} \mathrm{N}$ - 64 $35^{\circ} 906^{\prime \prime} \mathrm{W}$ and $5^{\circ} 28^{\prime} 12^{\prime \prime} \mathrm{N}-64^{\circ} 30^{\prime} 18^{\prime \prime} \mathrm{W}$ (Fig. 1), in order to encompass only those sites that were sampled across the four seasons and discard potential differences between locations. This segment subsample encompassed $12.32 \mathrm{~km}$ of the River Kakada.

Table 1. Characterisation of hydrological seasons and mesohabitats of the Kakada River

\begin{tabular}{|c|c|c|c|c|}
\hline \multicolumn{2}{|c|}{$\begin{array}{l}\text { Hydrological season or } \\
\text { mesohabitat }\end{array}$} & \multirow{2}{*}{$\begin{array}{c}\text { Code } \\
\mathrm{R}\end{array}$} & \multirow[t]{2}{*}{ Description } & \multirow{2}{*}{$\begin{array}{c}\text { N samples } \\
14\end{array}$} \\
\hline & Rising waters & & & \\
\hline రิ & High waters & $\mathrm{H}$ & September 2008. Water depth $>7 \mathrm{~m}$. & 12 \\
\hline$\tilde{\Xi}$ & Falling waters & $\mathrm{F}$ & November 2008. Average water depth $=4.14 \mathrm{~m}$. & 13 \\
\hline & Low waters & $\mathrm{L}$ & April 2009. Ending of dry season. Average water depth $=3.08 \mathrm{~m}$. & 12 \\
\hline \multirow{4}{*}{ 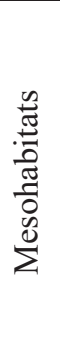 } & Clayey bottoms & $\mathrm{CB}$ & $\begin{array}{l}\text { Littorals with riparian forest and bottoms dominated by clay. Presence of } \\
\text { roots and submerged vegetation. }\end{array}$ & 20 \\
\hline & $\begin{array}{l}\text { Bottoms covered } \\
\text { with debris }\end{array}$ & $\mathrm{BD}$ & $\begin{array}{l}\text { Littorals with riparian forests with bottoms covered by fallen leaves, logs and } \\
\text { debris. }\end{array}$ & 10 \\
\hline & Rocky substrate & $\mathrm{RS}$ & $\begin{array}{l}\text { Rapids in the middle of the river channel with bottoms dominated by sub- } \\
\text { merged rocks. }\end{array}$ & 6 \\
\hline & Sandy bottoms & SB & $\begin{array}{l}\text { Littorals or islands in the middle of the river channel with open waters and } \\
\text { bottoms dominated by fine sands. }\end{array}$ & 15 \\
\hline
\end{tabular}


The taxonomic diversity of mesohabitats and seasons was obtained with Hill numbers of order q = 0,1 and 2, which are equivalent to species richness, the Shannon entropy and the inverse Simpson concentration respectively (Jost, 2006). The Hill number $\mathrm{q}=0$ represents the diversity of all species, whereas $q=1$ represents the diversity of commonly spread species and $\mathrm{q}=2$ represents the diversity of dominant species (Chao et al., 2014). The Hill

a)
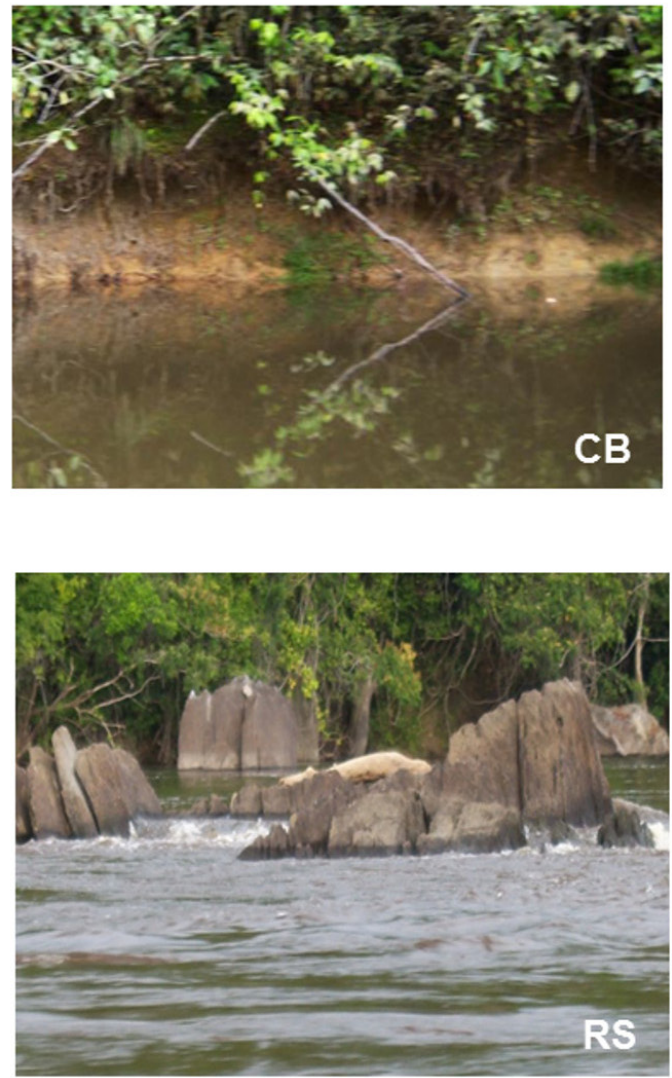

b)

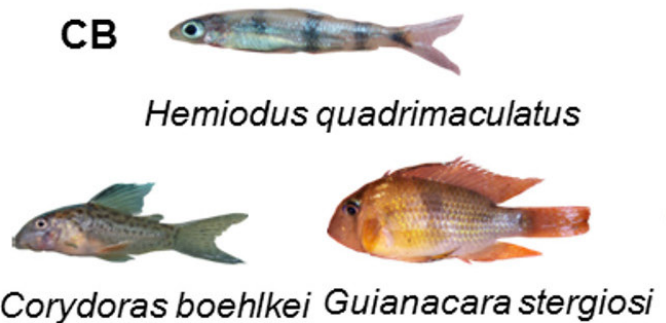

Corydoras boehlkei Guianacara stergiosi numbers are considered diversity indices that differ among themselves by the exponent q, which incorporates both species richness and relative abundances (Chao et al., 2014). The taxonomic diversities were calculated with a combined method of individual-based rarefactions and extrapolations (Chao \& Jost, 2012) of the abundances of fishes in each sample, based on 50 bootstrap replications using the package iNEXT (Hsieh et al., 2016).
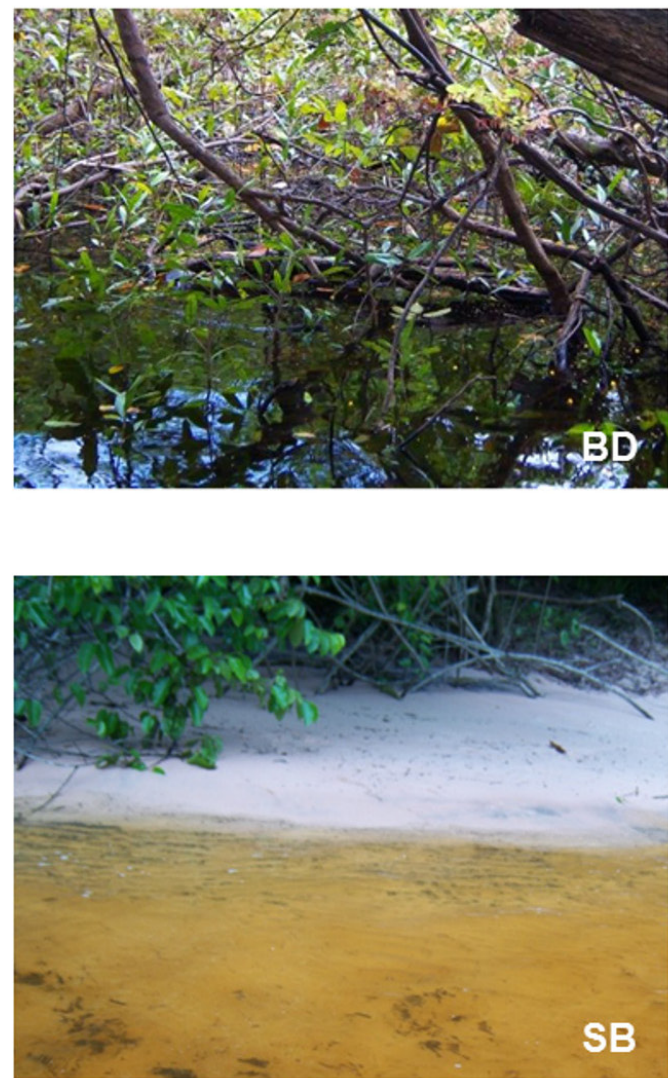

\section{BD}
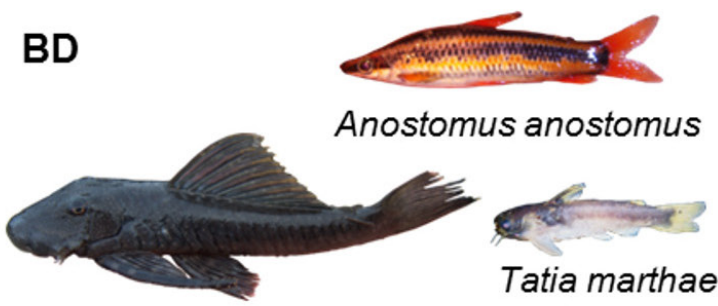

Chaetostoma vasquezi
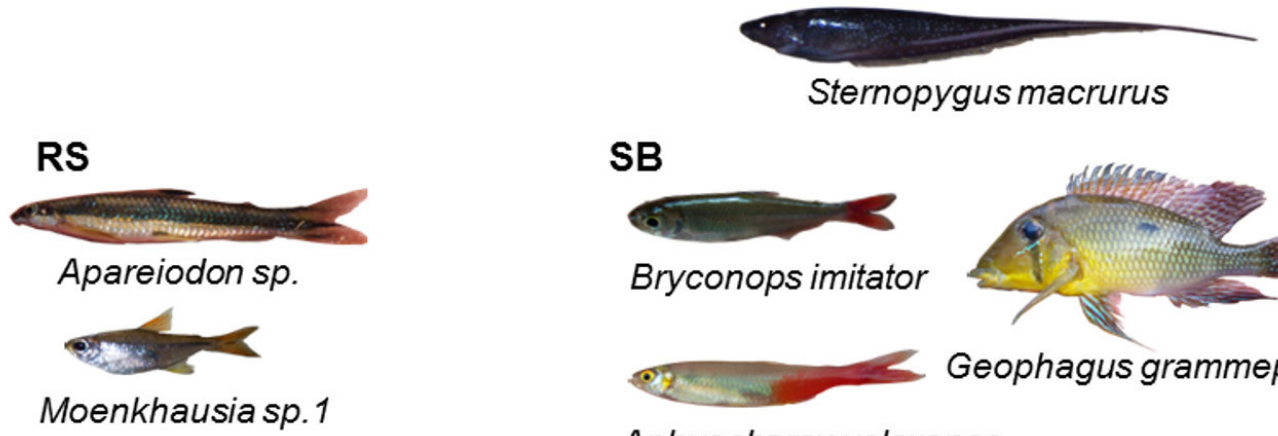

SB
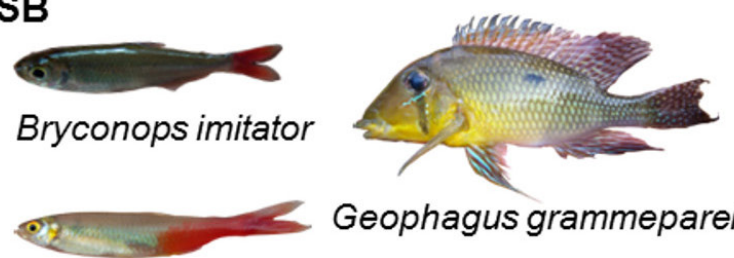

Geophagus grammepareius

\section{Aphyocharax yekwanae}

Fig. 2. a) Sampled mesohabitats: clayey bottoms (CS), bottoms covered by debris (BD), rocky substrates (RS) and sandy bottoms (SB). b) Some of the most frequent species per mesohabitat. 
The functional diversity was measured using the indices of functional richness, functional evenness, functional divergence and functional dispersion (Laliberté \& Legendre, 2010). The functional richness is equivalent to the convex hull of an ordination of the species traits; the functional evenness describes how even is the distribution of the species abundances in the functional trait space whereas the functional divergence indicates how distant are the most abundant species of the centroid of the functional space (Villéger et al., 2008). The functional dispersion represents the average distance of the species to the centroid of the functional space (Laliberté \& Legendre, 2010). All the indices were computed using a matrix of species traits and a matrix of species abundances per sample. The matrix of traits was transformed to Gower distances (Villéger et al., 2008) and the abundances of the species were used as weights. The calculations were done with the FD package (Laliberté et al., 2014) in R (R Development Core Team, 2012). Comparisons of the indices among mesohabitats and seasons were carried out through Kruskal-Wallis tests. The four indices of functional diversity were compared against null models in order to test if the observed indices by season and mesohabitat differed from random. These analyses were based on species incidence matrices that were compared against 999 simulated matrices under the independent swap null model (Gotelli, 2000) in which species occurrence frequencies and site species richness are maintained. Standard effect sizes were calculated for the four indices as: SES = (mean observed mean simulated)/SD simulated. The simulations were carried out with the function RandomizeMatrix () of the package for $\mathrm{R}$ picante (Kembel et al., 2010).

\section{Taxonomic diversity}

A total of 56 fish species were registered in the mesohabitats of the River Kakada during the entire sampling period. The species, their codes and traits are presented in Table 2 . The most frequent species per habitat are presented in Fig. 2b. There was not a significant heterogeneity in within groups dispersions among seasons $(\mathrm{F}=8.46 \mathrm{E}-2, \mathrm{df} 1=3$, df $2=$ $47, \mathrm{P}=0.96)$ or among mesohabitats $(\mathrm{F}=0.61, \mathrm{df1}$ $=3$, df $2=47, \mathrm{P}=0.70$ ) There were significant differences in the composition among hydrological seasons (Pseudo- $\mathrm{F}=1.86, \mathrm{P}=0.005$, $\mathrm{df}=3$ ), among mesohabitats (Pseudo-F $=3.36, \mathrm{P}=0.001$, $\mathrm{df}=3$ ) and the interaction of the two factors was also significant (Pseudo- $\mathrm{F}=1.32, \mathrm{P}=0.042, \mathrm{df}=7$ ), indicating changes in species composition within mesohabitats across hydrological seasons. Corydoras osteocarus
Böhlke, 1951, Aequidens chimantanus Inger, 1956, Pimelodella sp., and Brycon sp., were associated to falling waters, Moenkhausia cotinho Eigenmann, 1908 and Aparieodon sp., were associated to high waters, Hemigrammus schmardae (Steindachner, 1882) and Bryconops caudomaculatus (Günther, 1864 ) to rising waters and Bryconops giacopinii (Fernández-Yépez, 1950), Astyanax sp., and Knodus aff. victoriae (Steindachner, 1907) were associated to low waters (Fig. 3a). The pairwise PERMANOVA analysis indicated significant differences between rising and high waters, rising and falling waters, high and falling waters and between high and low waters (Table 3). There were no differences in fish species composition between rising and low waters or between falling and low waters, the convex hulls of which highly overlapped in Fig. 3a.

Likewise, the pair-wise PERMANOVA analysis indicated significant differences between clayey and sandy bottoms, clayey bottoms and rocky substrates, sandy bottoms and rocky substrates, and between sandy bottoms and bottoms covered with debris $(\mathrm{t}=2.22, \mathrm{P}$ $=0.002)$. The fish compositions of rocky substrates and bottoms covered with debris were marginally different (Table 3 ), the convex hulls of which slightly overlapped (Fig. 3b). There were not differences in species composition between clayey bottoms and bottoms covered with debris, as their convex hulls highly overlapped. Moenkhausia lepidura (Kner, 1858), Bryconops imitator Chernoff \& MachadoAllison, 2002, Geophagus grammepareius Kullander \& Taphorn, 1992 and Aphyocharax yekwanae Willink, Chernoff \& Machado-Allison, 2003 were associated to sandy bottoms, Moenkhausia sp.1 and Apareiodon sp., were associated to rocky substrates, Corydoras boehlkei Nijssen \& Isbrücker. 1982, Hemiodus quadrimaculatus Pellegrin, 1909 and Guianacara stergiosi López-Fernández, Taphorn Baechle \& Kullander, 2006 to littorals with riparian forest and clayey bottoms, whereas Anostomus anostomus (Linnaeus, 1758), Chaetostoma vasquezi Lasso \& Provenzano, 1998, Tatia marthae Vari \& Ferraris, 2013, Charax apurensis Lucena, 1987, Sternopygus macrurus (Bloch y Schneider, 1801) and Acarichthys sp., were associated to bottoms covered by debris (Fig. $2 \mathrm{~b}, 3 \mathrm{~b})$. The analysis of the segment subsample gave similar results, with significant differences between hydrological seasons (Pseudo-F $=1.92, \mathrm{P}=0.004$, df $=3$ ), among mesohabitat types (Pseudo-F $=3.24, \mathrm{P}$ $=0.001, \mathrm{df}=3)$ and a significant interaction between factors (Pseudo-F $=1.43, \mathrm{P}=0.014$, $\mathrm{df}=7$ ). The pairwise analyses indicated compositional differences between most seasons and mesohabitats (Table 3). 
Table 2. Taxonomic list of fishes in the mesohabitats of the River Kakada and their traits

\begin{tabular}{|c|c|c|c|c|c|c|c|}
\hline Order & Family & Species & $\begin{array}{l}\text { Species } \\
\text { code }\end{array}$ & $\begin{array}{c}\text { Size (mean SL } \\
\mathrm{cm})\end{array}$ & Diet & BS & MP \\
\hline \multirow{38}{*}{ Characiformes } & \multirow{2}{*}{ Acestrorhynchidae } & Acestrorhynchus falcatus & A.fal & 20 & carnivore & $\mathrm{F}$ & $\mathrm{T}$ \\
\hline & & Acestrorhynchus microlepis & A.mic & 15.5 & carnivore & $\mathrm{F}$ & $\mathrm{T}$ \\
\hline & Anostomidae & Anostomus anostomus & A.ano & 8 & invertivore & $\mathrm{F}$ & TS \\
\hline & Bryconidae & Brycon sp. & Bry & 15 & herbivore & $\mathrm{O}$ & $\mathrm{T}$ \\
\hline & \multirow{20}{*}{ Characidae } & Aphyocharax yekwanae & A.yek & 6.5 & invertivore & $\mathrm{F}$ & $\mathrm{T}$ \\
\hline & & Astyanax sp. & Ast & 9 & omnivore & $\mathrm{F}$ & $\mathrm{T}$ \\
\hline & & Brachychalcinus orbicularis & B.orb & 9 & invertivore & $\mathrm{O}$ & $\mathrm{T}$ \\
\hline & & Charax gr. apurensis & C.apu & 12.93 & carnivore & $\mathrm{H}$ & TS \\
\hline & & Cheirodon sp. & Che & 3 & zooplanktivore & $\mathrm{F}$ & $\mathrm{TI}$ \\
\hline & & Hemigrammus schmardae & H.sch & 2.8 & herbivore & $\mathrm{F}$ & $\mathrm{T}$ \\
\hline & & Hemigrammus sp. 1 & H.sp1 & 2 & herbivore & $\mathrm{G}$ & $\mathrm{T}$ \\
\hline & & Hemigrammus sp. gr. belloti & H.bel & 2.6 & herbivore & $\mathrm{F}$ & $\mathrm{T}$ \\
\hline & & Hemigrammus sp. & H.sp & 2.3 & herbivore & $\mathrm{F}$ & $\mathrm{T}$ \\
\hline & & Hyphesobrycon sp. 1 & Нyp & 3.8 & herbivore & $\mathrm{R}$ & $\mathrm{T}$ \\
\hline & & Jupiaba zonata & J.zon & 4.7 & herbivore & $\mathrm{O}$ & $\mathrm{T}$ \\
\hline & & Knodus aff. heterestes & K.het & 5.1 & invertivore & $\mathrm{F}$ & $\mathrm{T}$ \\
\hline & & Knodus aff. victoriae & K.vic & 4.5 & invertivore & $\mathrm{F}$ & $\mathrm{T}$ \\
\hline & & Knodus breviceps & K.bre & 6.3 & invertivore & $\mathrm{F}$ & $\mathrm{T}$ \\
\hline & & Moenkhausia cf.cotinho & M.cou & 10 & omnivore & $\mathrm{O}$ & $\mathrm{T}$ \\
\hline & & Moenkhausia collettii & M.col & 4.8 & omnivore & $\mathrm{F}$ & $\mathrm{T}$ \\
\hline & & Moenkhausia lepidura & M.lep & 9.5 & omnivore & $\mathrm{F}$ & $\mathrm{T}$ \\
\hline & & Moenkhausia oligolepis & M.oli & 8.45 & omnivore & $\mathrm{O}$ & $\mathrm{T}$ \\
\hline & & Moenkhausia sp. 1 & M.sp1 & 12.26 & omnivore & $\mathrm{F}$ & $\mathrm{T}$ \\
\hline & & Phenacogaster sp. 1 & Phe & 3.7 & herbivore & $\mathrm{R}$ & $\mathrm{T}$ \\
\hline & Crenuchidae & Melanocharacidium dispiloma & M.dis & 4.9 & invertivore & $\mathrm{C}$ & $\mathrm{T}$ \\
\hline & \multirow{3}{*}{ Curimatidae } & Curimata sp. & Cur & 6 & detritivore & $\mathrm{R}$ & $\mathrm{T}$ \\
\hline & & Cyphocharax sp. & Cyp & 7.5 & detritivore & $\mathrm{F}$ & $\mathrm{T}$ \\
\hline & & Steindachnerina cf. argentea & S.arg & 7.5 & detritivore & $\mathrm{R}$ & $\mathrm{T}$ \\
\hline & \multirow{2}{*}{ Erythrinidae } & Hoplias aimara & H.aim & 20.6 & carnivore & $\mathrm{C}$ & $\mathrm{T}$ \\
\hline & & Hoplias malabaricus & H.mal & 17 & carnivore & $\mathrm{C}$ & $\mathrm{T}$ \\
\hline & \multirow{2}{*}{ Hemiodontidae } & Hemiodus amazonum & H.ama & 12 & herbivore & $\mathrm{F}$ & $\mathrm{T}$ \\
\hline & & Hemiodus quadrimaculatus & H.qua & 16.8 & herbivore & $\mathrm{F}$ & $\mathrm{T}$ \\
\hline & \multirow{5}{*}{ Iguanodectidae } & Bryconops aff. humeralis & B.hum & 7.5 & invertivore & $\mathrm{F}$ & $\mathrm{T}$ \\
\hline & & Bryconops caudomaculatus & B.cau & 10.5 & invertivore & $\mathrm{F}$ & $\mathrm{T}$ \\
\hline & & Bryconops collettei & B.col & 7.8 & herbivore & $\mathrm{F}$ & $\mathrm{T}$ \\
\hline & & Bryconops giacopinii & B.gia & 11.2 & invertivore & $\mathrm{F}$ & $\mathrm{T}$ \\
\hline & & Bryconops imitator & B.imi & 10.4 & invertivore & $\mathrm{F}$ & $\mathrm{T}$ \\
\hline & Parodontidae & Apareiodon sp. & Apa & 5.9 & zooplanktivore & $\mathrm{F}$ & TI \\
\hline
\end{tabular}




\begin{tabular}{|c|c|c|c|c|c|c|c|}
\hline Order & Family & Species & $\begin{array}{l}\text { Species } \\
\text { code }\end{array}$ & $\begin{array}{c}\text { Size (mean SL } \\
\mathbf{c m})\end{array}$ & Diet & BS & MP \\
\hline \multirow{9}{*}{ Cichliformes } & \multirow{9}{*}{ Cichlidae } & Acarichthys sp. & Aca & 5 & detritivore & $\mathrm{O}$ & TI \\
\hline & & Aequidens chimantanus & A.chi & 8.5 & detritivore & $\mathrm{O}$ & $\mathrm{TI}$ \\
\hline & & Crenicichla cf.alta & C.alt & 15 & carnivore & $\mathrm{F}$ & $\mathrm{T}$ \\
\hline & & Crenicichla saxatilis & C.sax & 16 & carnivore & $\mathrm{F}$ & $\mathrm{T}$ \\
\hline & & Crenicichla sp. & Cre & 12 & carnivore & $\mathrm{F}$ & $\mathrm{T}$ \\
\hline & & Geophagus grammepareius & G.gra & 13 & herbivore & $\mathrm{O}$ & TI \\
\hline & & Guianacara geayi & G.gea & 10 & detritivore & $\mathrm{O}$ & TI \\
\hline & & Guianacara stergiosi & G.ste & 10.2 & detritivore & $\mathrm{O}$ & $\mathrm{TI}$ \\
\hline & & Satanoperca sp. & Sat & 12.8 & detritivore & $\mathrm{O}$ & $\mathrm{TI}$ \\
\hline \multirow{2}{*}{ Gymnotiformes } & \multirow{2}{*}{ Sternopygidae } & Eigenmannia virescens & E.vir & 11.5 & zooplanktivore & $\mathrm{E}$ & $\mathrm{T}$ \\
\hline & & Sternopygus macrurus & S.mac & 55.78 & carnivore & $\mathrm{E}$ & $\mathrm{T}$ \\
\hline \multirow{7}{*}{ Siluriformes } & Auchenipteridae & Tatia marthae & T.mar & 2.3 & zooplanktivore & $\mathrm{C}$ & $\mathrm{T}$ \\
\hline & \multirow{2}{*}{ Loricariidae } & Chaetostoma vasquezi & C.vas & 18 & detritivore & $\mathrm{Fl}$ & V \\
\hline & & Hypostomus sp gr. cochliodon & H.coc & 16 & detritivore & $\mathrm{Fl}$ & V \\
\hline & \multirow{2}{*}{ Callichthyidae } & Corydoras boehlkei & C.boe & 2.6 & invertivore & $\mathrm{C}$ & V \\
\hline & & Corydoras osteocarus & C.ost & 3.2 & invertivore & $\mathrm{C}$ & V \\
\hline & \multirow{2}{*}{ Heptapteridae } & Pimelodella sp. & P.sp & 14 & omnivore & $\mathrm{C}$ & TI \\
\hline & & Pimelodella sp. 1 & P.sp1 & 17 & omnivore & $\mathrm{C}$ & $\mathrm{TI}$ \\
\hline
\end{tabular}

Note: BS - body shape, F - fusiform, Fl - flattened, C - cylindrical, E - elongated, H - humped, O - oval, R - rhomboid, MP - mouth position, T - terminal, TI - terminal inferior, TS - terminal superior, V - ventral
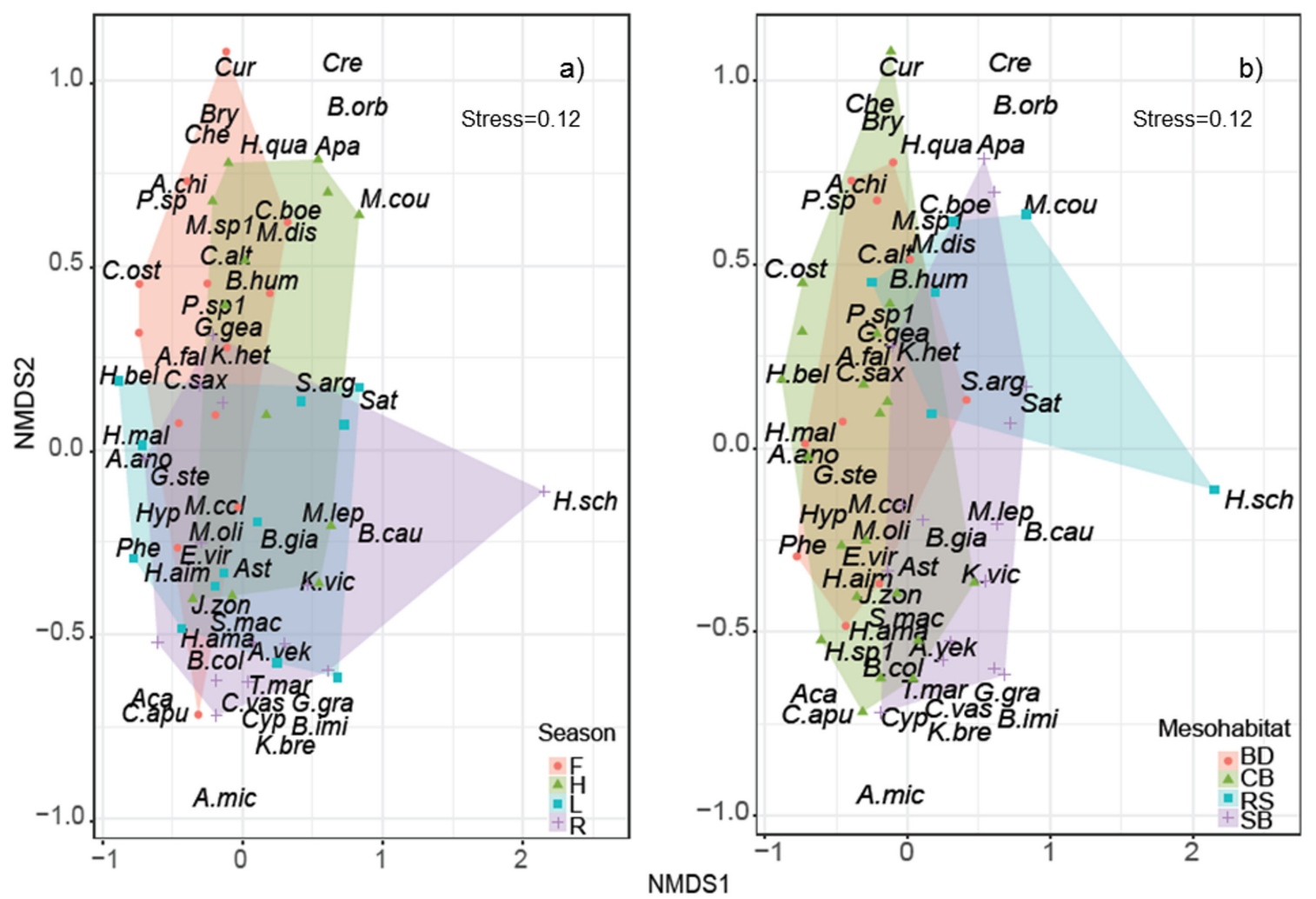

Fig. 3. Non-metric multidimensional scaling (NMDS) of species abundances a) by season and b) by mesohabitat. 
Table 3. Results of the pairwise PERMANOVA analyses. Panels on the left correspond to the results of the entire sampled segment, based on 51 samples. Panels on the right correspond to the results of only those samples between $5^{\circ} 30^{\prime} 32.4^{\prime \prime} \mathrm{N}-$ $64^{\circ} 35^{\prime} 906^{\prime \prime} \mathrm{W}$ and $5^{\circ} 28^{\prime} 12^{\prime \prime} \mathrm{N}-64^{\circ} 30^{\prime} 18^{\prime \prime} \mathrm{W}$

\begin{tabular}{|c|c|c|c|c|c|c|c|c|c|}
\hline \multicolumn{5}{|c|}{ Season } & \multicolumn{5}{|c|}{ Mesohabitat } \\
\hline \multicolumn{10}{|c|}{ Entire segment } \\
\hline Groups & $\mathrm{t}$ & $\mathrm{P}$ & Perm & $\mathrm{DF}$ & Groups & $\mathrm{t}$ & $\mathrm{P}$ & Perm & $\mathrm{DF}$ \\
\hline $\mathrm{R}, \mathrm{H}$ & 1.53 & 0.01 & 997 & 19 & $\mathrm{CS}, \mathrm{SB}$ & 2.41 & 0.00 & 999 & 27 \\
\hline $\mathrm{R}, \mathrm{F}$ & 1.49 & 0.02 & 999 & 20 & $\mathrm{CS}, \mathrm{RS}$ & 1.51 & 0.01 & 998 & 19 \\
\hline $\mathrm{R}, \mathrm{L}$ & 0.89 & 0.6 & 999 & 20 & $\mathrm{CS}, \mathrm{BD}$ & 0.81 & 0.73 & 998 & 23 \\
\hline $\mathrm{H}, \mathrm{F}$ & 1.57 & 0.01 & 999 & 17 & $\mathrm{SB}, \mathrm{RS}$ & 1.58 & 0.01 & 999 & 14 \\
\hline $\mathrm{H}, \mathrm{L}$ & 1.4 & 0.03 & 997 & 17 & $\mathrm{SB}, \mathrm{BD}$ & 2.22 & 0.00 & 998 & 18 \\
\hline $\mathrm{F}, \mathrm{L}$ & 0.79 & 0.75 & 999 & 18 & RS, BD & 1.43 & 0.07 & 998 & 10 \\
\hline \multicolumn{10}{|c|}{ Segment subsample } \\
\hline $\mathrm{R}, \mathrm{H}$ & 2.37 & 0.00 & 997 & 16 & $\mathrm{CS}, \mathrm{SB}$ & 2.37 & 0.00 & 997 & 22 \\
\hline $\mathrm{R}, \mathrm{F}$ & 1.49 & 0.01 & 999 & 19 & CS, RS & 1.49 & 0.01 & 999 & 16 \\
\hline $\mathrm{R}, \mathrm{L}$ & 0.62 & 0.93 & 999 & 12 & $\mathrm{CS}, \mathrm{BD}$ & 0.62 & 0.93 & 999 & 19 \\
\hline $\mathrm{H}, \mathrm{F}$ & 1.61 & 0.02 & 999 & 15 & $\mathrm{SB}, \mathrm{RS}$ & 1.61 & 0.02 & 999 & 12 \\
\hline $\mathrm{H}, \mathrm{L}$ & 2.22 & 0.00 & 999 & 9 & $\mathrm{SB}, \mathrm{BD}$ & 2.22 & 0.00 & 999 & 15 \\
\hline $\mathrm{F}, \mathrm{L}$ & 1.34 & 0.10 & 999 & 22 & RS, BD & 1.34 & 0.10 & 999 & 9 \\
\hline
\end{tabular}

Note: Perm $=$ number of permutations, $\mathrm{DF}=$ degrees of freedom.

Rising water was the hydrological season with the highest species richness and diversities (Table 4, Fig. 4a). The lowest species richness was observed during falling waters, although the lowest species diversities were observed during low waters. The curve for species richness: $q=0$, increased steeply with sample size for rising, high and falling waters, whereas for low waters the curve stabilised with less observed specimens. Contrastingly, the curves of $q=1$ and $q=2$ for Shannon and Simpsons indices respectively, stabilised much sooner, indicating that the seasonal diversities were influenced by the abundances of the most common species. The confidence intervals of the curves of rising and high waters overlapped for the Shannon and Simpson diversities, suggesting that the fish diversities during these hydrological seasons were not very different. The mesohabitat with the highest species richness and diversities was the clayey bottoms (Table 4, Fig. 4b). The rocky substrates harboured the lowest species richness and diversities. The curve for species richness of sandy bottoms stabilised at larger sample sizes with respect to the other mesohabitats, suggesting a high effect of the dominant fish species. All the diversity curves of bottoms covered with debris and rocky substrates indicated a good coverage of the fish diversity in these mesohabitats.

\section{Functional diversity}

The ordination plot of fish species by their traits (Fig. 5a) indicated that the species were ordered according to their trophic guilds in axis 1 and according to their body shape in axis 2 . The size and mouth position showed little variation. The orders Characiformes and Siluriformes had higher functional richness, shown by their larger convex hulls. In general terms, Siluriformes exhibited flat or cylindrical bodies, with mouths positions mostly ventral and terminal-inferior, and belonged to the omnivore, algivorezooplanktivore and omnivore trophic guilds. The Characiformes exhibited a greater variation in their traits, for instance Hoplias aimara (Valenciennes, 1847) and H. malabaricus (Bloch, 1794) had cylindrical bodies and carnivore trophic guild, Curimata sp., Steindachnerina cf. argentea and Phenacogaster sp. exhibited rhomboid bodies and detritivore trophic guilds, and $A$. anostomus and Melanocharacidium dispiloma Buckup, 1993 exhibited fusiform bodies and invertivore trophic guild. Contrastingly, most Cichliformes exhibited oval bodies with mouth in terminalinferior positions and detritivore guilds, with the exception of Crenicichla spp., whereas the two Gymnotiformes exhibited elongated bodies with mouths in terminal position. 
Table 4. Fish species diversity per hydrological season and within the mesohabitats of the River Kakada

\begin{tabular}{|c|c|c|c|c|}
\hline \multicolumn{2}{|c|}{} & Species richness $(\mathrm{q}=0)$ & Shannon Index $(\mathrm{q}=1)$ & Simpson Index $(\mathrm{q}=2)$ \\
\hline \multirow{4}{*}{ Seasons } & $\mathrm{R}$ & 32 & 9.76 & 6.7 \\
\cline { 2 - 5 } & $\mathrm{H}$ & 20 & 8.02 & 6.26 \\
\cline { 2 - 5 } & $\mathrm{F}$ & 16 & 4.84 & 3.05 \\
\cline { 2 - 5 } & $\mathrm{L}$ & 22 & 3.99 & 2.21 \\
\hline \multirow{5}{*}{ Mesohabitats } & $\mathrm{BD}$ & 26 & 6.92 & 4.27 \\
\cline { 2 - 5 } & $\mathrm{CS}$ & 35 & 10.2 & 5.98 \\
\cline { 2 - 5 } & RS & 14 & 3.94 & 2.15 \\
\cline { 2 - 5 } & SB & 32 & 5.26 & 3 \\
\hline
\end{tabular}

a)
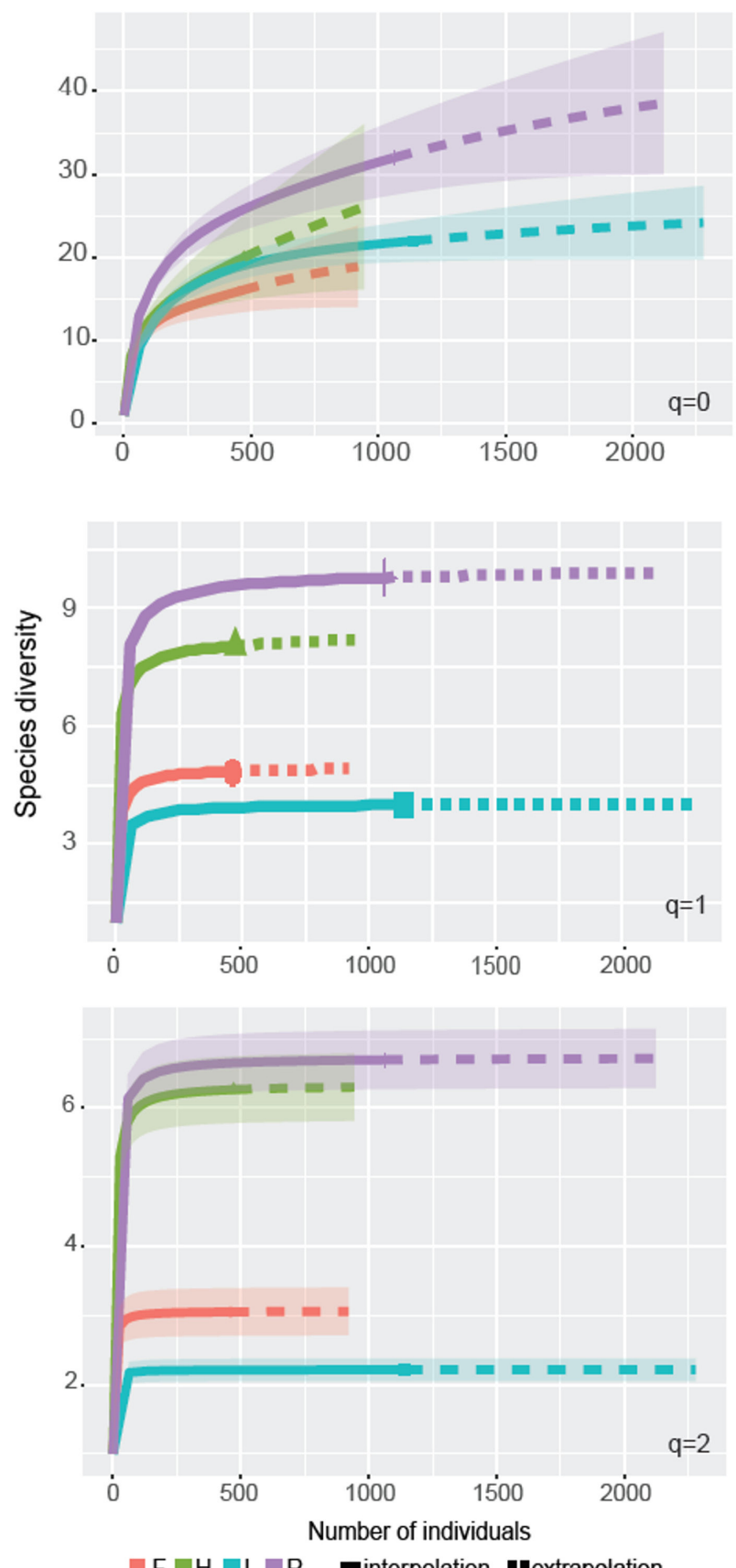

b)
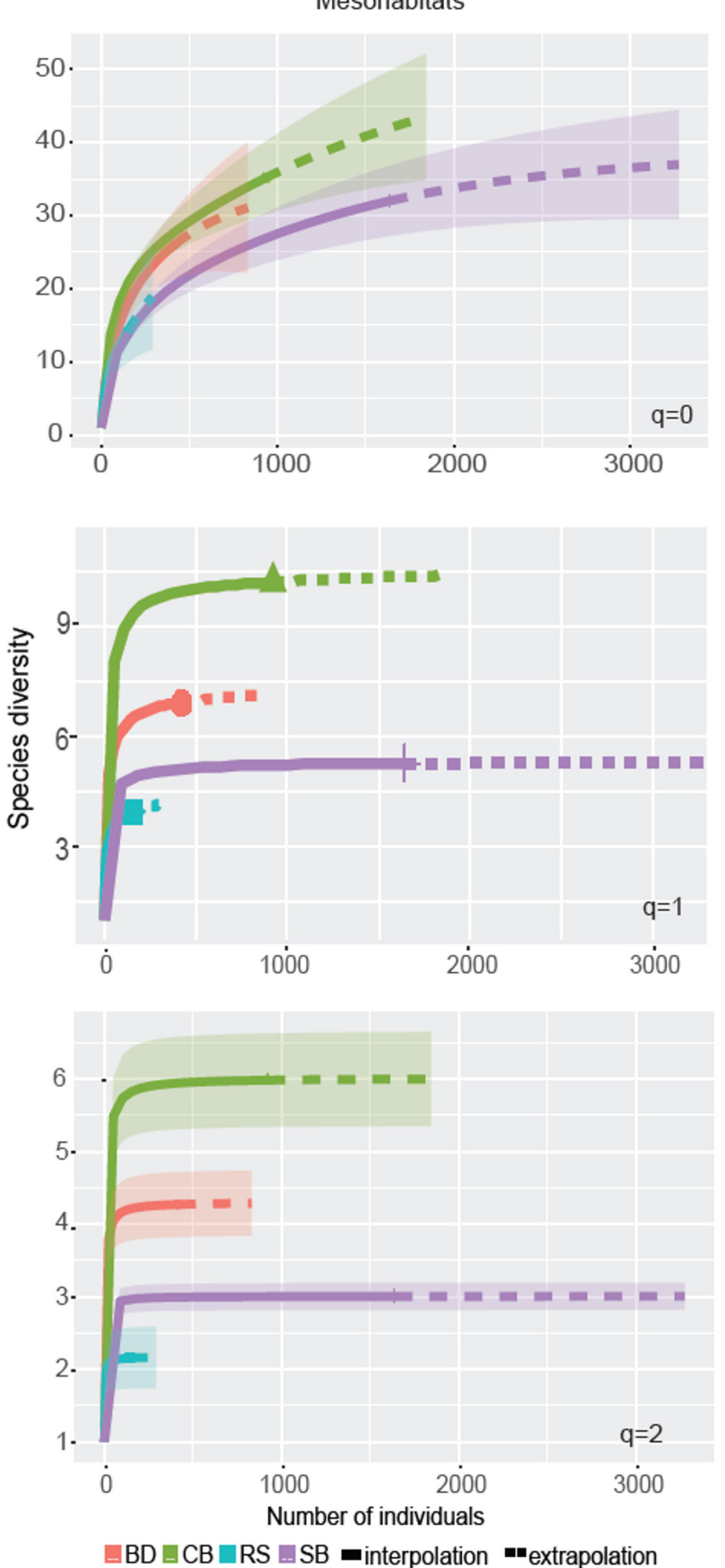

Fig. 4. a) Species diversities by Hill-numbers $q=0, q=1$ and $q=2$ : a) per mesohabitat and b) per season. 

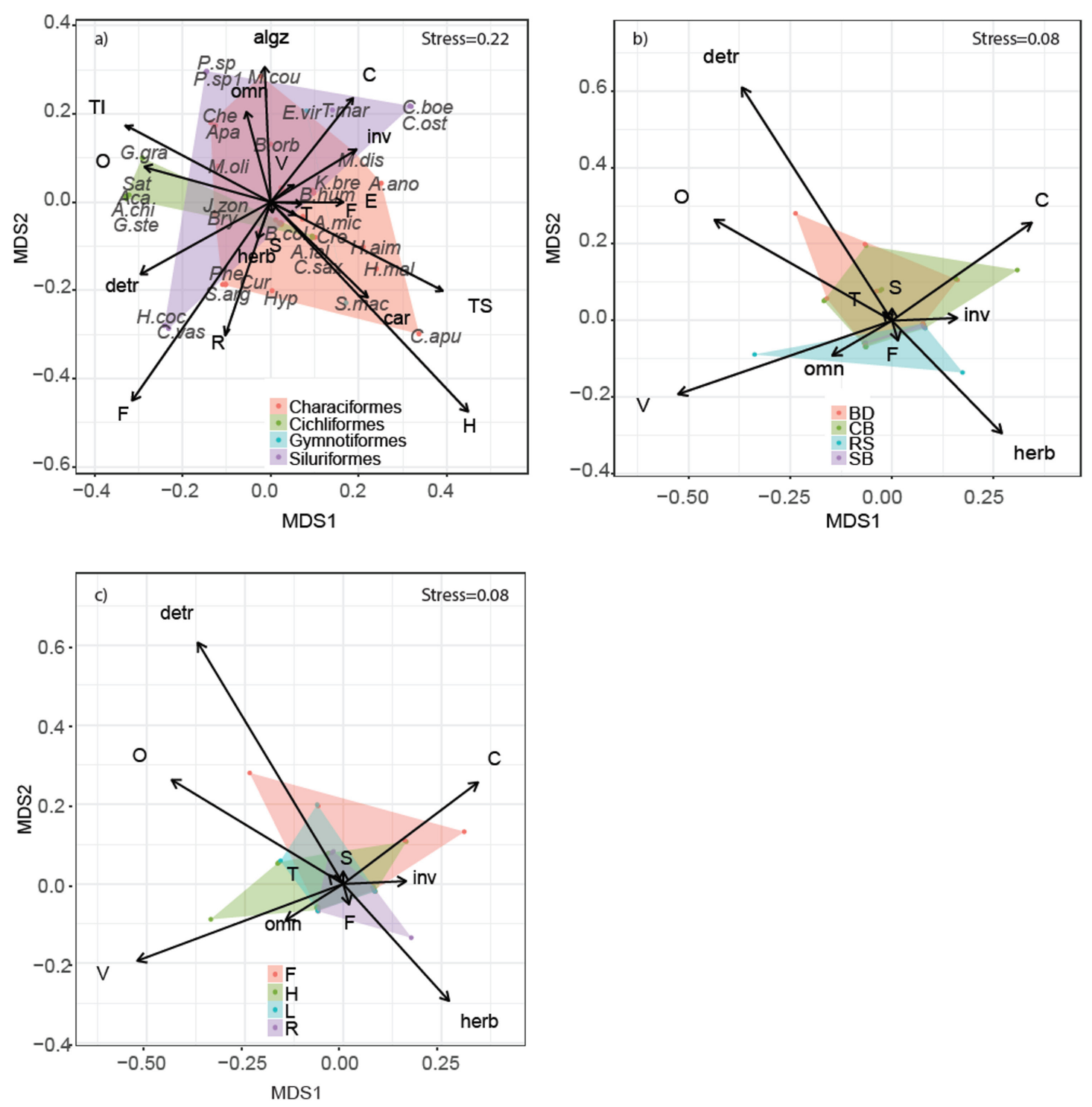

Fig. 5. NMDSs: a) of species by their traits, b) of traits by mesohabitat and c) of traits by season.

Contrarily to the patterns of taxonomic composition, there were no significant differences in fish traits among hydrological seasons (Pseudo-F $=1.13, \mathrm{P}=$ $1.88, \mathrm{df}=3)$, and the interaction between mesohabitat and season was not significant either (Pseudo-F $=$ $4.33, \mathrm{P}=0.001, \mathrm{df}=3)$. The only significant differences in fish functional composition were observed among mesohabitats (Pseudo-F $=1.20, \mathrm{P}=0.33$, $\mathrm{df}=7$ ). This pattern was maintained in the analysis of the subsampled segment (season $=$ Pseudo-F $=1.11, \mathrm{P}=$ $0.37, \mathrm{df}=3$; mesohabitat $=$ Pseudo- $\mathrm{F}=7.99, \mathrm{P}=0.001$, $\mathrm{df}=3$; interaction $=$ Pseudo- $\mathrm{F}=1.34, \mathrm{P}=0.23, \mathrm{df}=7$ ). The pairwise analysis indicated there were significant differences in the fish functional composition between clayey and sandy bottoms, and between the former and bottoms covered by debris (Table 4). These differences were maintained in the subsampled segment analysis. The other mesohabitats did not show differences in their fish functional composition, as their convex hulls overlapped (Fig. 5b). The rocky substrates were associated to the fusiform body shape, mouths in ventral position and the omnivore and the herbivore trophic guild, the bottoms covered with debris were related to oval bodies and the detritivore guild, the littorals with riparian forest and clayey bottoms were associated to cylindrical bodies and the invertivore guild, and the sandy bottoms to fusiform bodies and to the invertibore guild. Even though the convex hulls of the seasons tended to overlap, there were some differences in their size and the variables they were associated to (Fig. 5c). The convex hull during falling waters was associated to the detritivore guild and the cylindrical body shape. The convex hull in high waters was associated to the ventral body shape while that of rising waters was associated to the herbivore trophic guild. 
Table 4. Results of pairwise PERMANOVA analyses of functional composition

\begin{tabular}{|c|c|c|c|c|c|c|c|c|c|c|}
\hline \multicolumn{7}{|c|}{ Entire segment } \\
\hline \multicolumn{9}{|c|}{ Mesohabitats } \\
\hline Groups & $\mathrm{t}$ & $\mathrm{P}$ & Perm & DF & Groups & $\mathrm{t}$ & $\mathrm{P}$ & Perm & DF \\
\hline CS, SB & 3.72 & 0.00 & 999 & 27 & R, H & 2.64 & 0.01 & 999 & 19 \\
\hline CS, RS & 1.65 & 0.08 & 999 & 19 & R, F & 0.88 & 0.43 & 999 & 20 \\
\hline CS, BD & 0.97 & 0.39 & 998 & 23 & R, L & 0.79 & 0.5 & 998 & 20 \\
\hline SB, RS & 0.71 & 0.5 & 999 & 14 & H, F & 1.18 & 0.27 & 999 & 17 \\
\hline SB, BD & 2.82 & 0.00 & 997 & 18 & H, L & 0.4 & 0.78 & 998 & 17 \\
\hline RS, BD & 0.46 & 0.86 & 997 & 10 & F, L & 0.97 & 0.36 & 999 & 18 \\
\hline & & & & Segment subsample & & & \\
\hline Groups & $\mathrm{t}$ & P & Perm & DF & Groups & t & P & Perm & DF \\
\hline CS, SB & 4.91 & 0.00 & 999 & 27 & R, H & 1.54 & 0.10 & 999 & 19 \\
\hline CS, RS & 2.18 & 0.01 & 999 & 19 & R, F & 0.95 & 0.43 & 999 & 20 \\
\hline CS, BD & 1.46 & 0.12 & 998 & 23 & R, L & 0.78 & 0.51 & 998 & 20 \\
\hline SB, RS & 1.35 & 0.18 & 999 & 14 & H, F & 1.25 & 0.21 & 999 & 17 \\
\hline SB, BD & 3.10 & 0.00 & 997 & 18 & H, L & NA & NA & NA & 17 \\
\hline RS, BD & 1.45 & 0.13 & 997 & 10 & F, L & 1.35 & 0.19 & 999 & 18 \\
\hline
\end{tabular}

Note: Perm $=$ number of permutations, $\mathrm{DF}=$ degrees of freedom.

Similarly, the Kruskal-Wallis tests did not detect seasonal differences in any of the functional diversity indices (Table 5). Nevertheless, the functional evenness and dispersion were higher during high waters (Fig. 6), and the lowest functional divergence was observed during falling waters. There were significant differences among mesohabitats in functional richness, functional evenness and functional dispersion but not in functional divergence, the values of which ranged from 0.76 for rocky substrates and 0.8 for bottoms covered by debris. The bottoms covered by debris and the clayey bottoms showed the highest functional richness, evenness and dispersion (Fig. 6). The sandy bottoms showed the lowest values of functional evenness and dispersion, but the functional richness was slightly higher than in the rocky substrates.

Table 5. Kruskal-Wallis test results of comparisons of functional indices among seasons and mesohabitats

\begin{tabular}{|l|c|c|c|}
\hline \multicolumn{4}{|c|}{ Season } \\
\hline Functional index & $\mathrm{K}$ & $\mathrm{P}$ & $\mathrm{DF}$ \\
\hline FRic & 1.17 & 0.76 & 3 \\
\hline FEve & 2.3 & 0.51 & 3 \\
\hline FDiv & 4.12 & 0.24 & 3 \\
\hline FDis & 4.46 & 0.21 & 3 \\
\hline \multicolumn{4}{|c|}{ Mesohabitat } \\
\hline FRic & 9.02 & 0.03 & 3 \\
\hline FEve & 7.23 & 0.06 & 3 \\
\hline FDiv & 1.38 & 0.71 & 3 \\
\hline FDis & 16.59 & 0 & 3 \\
\hline
\end{tabular}

Note $:$ FRic $=$ functional richness, FEve = functional evenness, FDiv $=$ functional divergence, FDis $=$ functional dispersion.
The comparison of the functional indices to null models indicated that the functional dispersion was lower than random during all seasons and in all mesohabitats (Table 6), and the functional richness was lower than random during falling and low waters, and on the rocky substrates. The functional evenness was not different from random in all cases, whereas the functional divergence was marginally lower than expected during falling waters and within bottoms covered by debris, and significantly lower than expected during rising waters and on clayey substrates and sandy beaches. These results suggest a tendency towards trait underdispersion in all mesohabitats and seasons.

\section{Discussion}

The mesohabitats of the River Kakada showed different taxonomic compositions and diversities, and also exhibited marked changes in species composition across hydrological seasons, suggesting an important temporal turnover. However, the functional compositions and diversities within mesohabitats did not change seasonally, indicating that across the hydrological season, there is a replacement of species that are functionally rather similar. This pattern deviates from the one observed in mesohabitats of the floodplain lakes of the lower River Caura, where both the taxonomic and functional diversities varied seasonally (Echevarría \& González, 2018), along with the taxonomic composition (Echevarría \& González, 2017). In other Neotropical rivers, seasonal variations in functional dispersion have been related to seasonal species 
turnover and changes in their frequencies of occurrence (Fitzgerald et al., 2017). Nevertheless, our analyses indicated seasonal differences in frequencies and composition of fishes did not generate changes in any of the measured attributes of their functional diversity.

The compositional changes within mesohabitats across seasons could be explained by the variations in the water level, which propitiate reshuffling in the organisation of the assemblages (Arrington \& Winemiller, 2006), suggesting a considerable influence of stochastic processes of dispersion and colonisation. On the other hand, there were also marked differences in species composition among mesohabitats, and some species showed preferences for certain mesohabitat types, indicating differential responses to certain habitat features, which might be associated to their specific adaptations to distinct habitat configurations, as well as to interspecific interactions (Arrington et al., 2005). The fishes adaptations to habitat configurations can be inferred from the observed trait - mesohabitat associations in the River Kakada.

The fish taxonomic diversity fluctuated seasonally as well. The different hill numbers can provide information about the patterns of species diversity and the effects of widespread and dominant species (Chao et al., 2014). In this case, they highlighted an effect of such species during falling waters, when the diversity was higher in comparison to low waters, despite the higher species richness of the latter. However, the highest diversities were observed during rising and high waters, a pattern that could be the result of an increased availability of habitat and trophic resources due to the flooding of the riparian forests (Junk et al., 1989). In a similar fashion, the diversity patterns of the sandy bottoms were influenced by the relative abundances of the most common species, mainly small characins. The highest diversities were observed in the mesohabitats with presence of riparian forest, a factor that is determinant in the distribution and diversity of fishes in the upper River Caura basin (Chernoff et al., 2003), along with the accumulation of leaf litter and debris (Machado-Allison et al., 2003). Higher diversity in these mesohabitats could be associated to their higher structural complexity, which might enable the coexistence of numerous species through partitioning of microhabitat and trophic niches (Willis et al., 2005).

The most important traits determining the species position in the functional space were the trophic guild and the body shape, which implies the fish assemblages in the mesohabitats of the River Kakada partition their niches according to trophic resource and habitat uses. Characiformes and Siluriformes occupied the most functional space. The convex hull of Siluriformes was determined by three points represented by the flat bodied detritivore Loricariids, the cylindrical bodied and invertivore Corydoras spp., and the slender omnivore Pimelodella spp. The traits exhibited by the Loricariids, particularly the flat bodies and the mouths in terminal position with mandibles specialised in gauging wood (Lujan et al., 2012) enabled them to forage on bottoms with debris that included logs, in a similar trend as in floodplain lakes of the lower River Caura (Echevarría \& González, 2018). The Characiformes exhibited a wider combination of traits and their functional space was occupied by more species in a less divergent pattern than that of Siluriformes. This allowed them to be present in all mesohabitat types. With the exception of Crenicichla spp., most cichlids were functionally similar: detritivores with oval body shapes and mouths in terminal-inferior position. These traits are associated to foraging on soft substrates such as sandy bottoms (CochranBiederman \& Winemiller, 2010) as it was observed in the sediment sifter G. grammepareius, although some species were associated to clayey substrates, such as Guiannacara spp., but these latter are considered generalist feeders (López-Fernández et al., 2014).
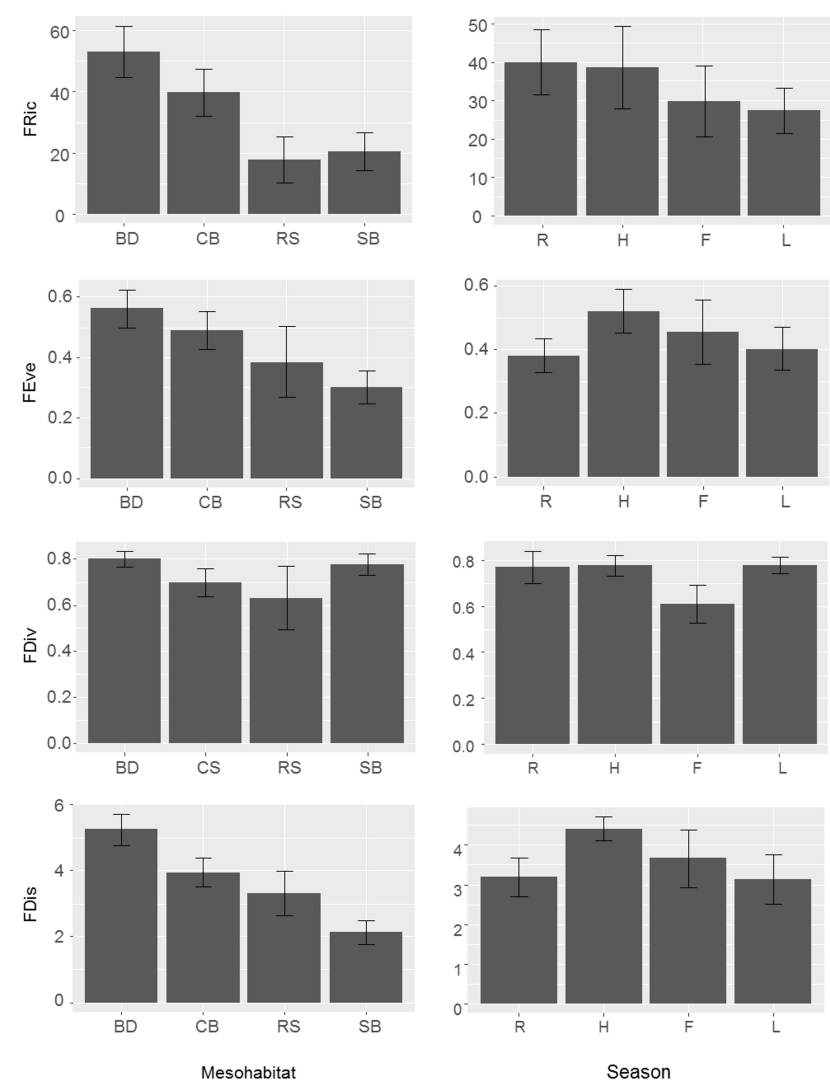

Fig. 6. Functional richness (FRic), functional evenness (FEve) and functional dispersion (FDis) of fishes in of the River Kakada by mesohabitat and hydrological season. 
Table 6. Results of the comparisons of the observed functional indices to simulated matrices under the independent swap null model

\begin{tabular}{|c|c|c|c|c|c|c|c|c|c|}
\hline \multicolumn{10}{|c|}{ FRic } \\
\hline Season & Obs & Sim & $\mathrm{P}$ & SES & Mesohabitat & Obs & Sim & $\mathrm{P}$ & SES \\
\hline $\mathrm{R}$ & $1.02 \mathrm{E}-15$ & $1.03 \mathrm{E}-15$ & 0.37 & -0.51 & $\mathrm{BD}$ & $2.79 \mathrm{E}-19$ & $1.95 \mathrm{E}-16$ & 0.50 & -0.34 \\
\hline $\mathrm{H}$ & $1.15 \mathrm{E}-20$ & $1.29 \mathrm{E}-17$ & 0.49 & -0.25 & $\mathrm{CS}$ & $4.40-16$ & $1.98 \mathrm{E}-15$ & 0.18 & -0.73 \\
\hline $\mathrm{F}$ & $2.43 \mathrm{E}-25$ & $2.59 \mathrm{E}-19$ & 0.002 & -0.12 & $\mathrm{RS}$ & $1.24 \mathrm{E}-34$ & $4.06 \mathrm{E}-21$ & 0.01 & -0.08 \\
\hline $\mathrm{L}$ & $1.31 \mathrm{E}-21$ & $3.97 \mathrm{E}-17$ & 0.03 & -0.32 & SB & $3.78 \mathrm{E}-18$ & $1.05 \mathrm{E}-15$ & 0.38 & -0.54 \\
\hline \multicolumn{10}{|c|}{ FEve } \\
\hline Season & Obs & Sim & $\mathrm{P}$ & SES & Mesohabitat & Obs & Sim & $\mathrm{P}$ & SES \\
\hline $\mathrm{R}$ & 0.4 & 0.41 & 0.92 & 1.41 & $\mathrm{BD}$ & 0.49 & 0.48 & 0.68 & 0.48 \\
\hline $\mathrm{H}$ & 0.47 & 0.41 & 0.87 & 1.11 & $\mathrm{CS}$ & 0.32 & 0.42 & 0.25 & -0.66 \\
\hline $\mathrm{F}$ & 0.45 & 0.51 & 0.12 & -1.15 & $\mathrm{RS}$ & 0.52 & 0.56 & 0.43 & -0.16 \\
\hline $\mathrm{L}$ & 0.34 & 0.49 & 0.26 & -0.58 & SB & 0.41 & 0.42 & 1.00 & 3.24 \\
\hline \multicolumn{10}{|c|}{ FDiv } \\
\hline Season & Obs & Sim & $\mathrm{P}$ & SES & Mesohabitat & Obs & Sim & $\mathrm{P}$ & SES \\
\hline $\mathrm{R}$ & 0.69 & 0.85 & 0.00 & -2.8 & $\mathrm{BD}$ & 0.83 & 0.85 & 0.06 & -1.69 \\
\hline $\mathrm{H}$ & 0.77 & 0.86 & 0.1 & -1.44 & $\mathrm{CS}$ & 0.79 & 0.85 & 0.04 & -1.84 \\
\hline $\mathrm{F}$ & 0.73 & 0.87 & 0.08 & -1.6 & $\mathrm{RS}$ & 0.63 & 0.86 & 0.13 & -1.24 \\
\hline $\mathrm{L}$ & 0.68 & 0.85 & 0.14 & -1.19 & SB & 0.67 & 0.86 & 0.02 & -2.08 \\
\hline \multicolumn{10}{|c|}{ FDis } \\
\hline Season & Obs & Sim & $\mathrm{P}$ & SES & Mesohabitat & Obs & Sim & $\mathrm{P}$ & SES \\
\hline $\mathrm{R}$ & 0.07 & 9.07 & 0.001 & -0.83 & $\mathrm{BD}$ & 0.12 & 8.69 & 0.001 & -0.68 \\
\hline $\mathrm{H}$ & 0.1 & 8.86 & 0.001 & -0.83 & $\mathrm{CS}$ & 0.09 & 8.75 & 0.001 & -0.82 \\
\hline $\mathrm{F}$ & 0.08 & 7.91 & 0.001 & -0.59 & $\mathrm{RS}$ & 0.06 & 6.21 & 0.001 & -0.6 \\
\hline $\mathrm{L}$ & 0.05 & 6.44 & 0.001 & -0.59 & SB & 0.04 & 7.61 & 0.001 & -0.63 \\
\hline
\end{tabular}

Note $:$ FRic $=$ functional richness, FEve $=$ functional evenness, FDiv $=$ functional divergence, FDis $=$ functional dispersion, Obs $=$ observed value, $\mathrm{Sim}=$ mean of simulations, $\mathrm{SES}=$ standardised effect size.

Each mesohabitat type was associated to certain fish traits, in a manner that seems to reflect the species adaptations to the substrate structure and also to the particular trophic resources they offer. Some of the observed fish trait - mesohabitat associations were similar to those observed in the floodplain lakes of the lower River Caura (Echevarría \& González, 2018), such as that between sandy bottoms and invertivores and that between the bottoms covered by debris with detritivores, suggesting the origin of these associations might be related to the trophic resources within these mesohabitats. The rocky substrates were associated to herbivores, mouths in ventral position and fusiform bodies, such as that of Apareiodon sp., a specialist in fast currents that scraps algae from the surface or rocks with its specialised mandibles (Casatti \& Castro, 2006). The combination of fish traits associated to rocky substrates was very different from those traits associated to the other mesohabitats, which highlights the influence of the environmental conditions such as the current velocity and substrate type in the assem- blage structure within these mesohabitats.

The index of functional richness indicated the rocky substrates had the smallest functional space in comparison to the other mesohabitats. This mesohabitat also had lower functional richness than randomly expected. These results suggest fast currents in this mesohabitats might act as filters (Weiher \& Keddy, 2004), favouring only a limited array of fish traits and constraining the size of the realised functional space. Contrastingly, the larger functional spaces were observed in the mesohabitats with presence of riparian forest. The structural complexity of the mesohabitats in rivers of the Guiana Shield favours the coexistence of a high diversity of fishes, as a result of a wider variety of trophic resources (Cilleros et al., 2017), which might enable the coexistence of species with different traits to exploit specific resources such as periphyton and benthic macroinvertebrates, and that are adapted to specific microhabitats. However, the functional richness was not higher than randomly expected in these mesohabitats. 
In a similar trend to the functional richness, the functional evenness and dispersion were higher in the clayey substrates with riparian forest and in the bottoms covered by debris. Therefore, in the habitats with presence of riparian forests the functional spaces were larger; more regularly filled by the species, and these were more dispersed from the assemblages' centroids in comparison to the rocky substrates or the sandy bottoms. On the contrary, there were not differences in the functional divergence among mesohabitats, indicating that the distribution of species abundances within their functional spaces was similar. These patterns reveal that in the mesohabitats with presence of riparian forests there was a higher degree of functional specialisation, and also that the occupation of the functional space increased with species richness, in a similar trend to other fish communities (Winemiller, 1991; Pease et al., 2012). Nevertheless, the comparisons of the functional indices with null models did not provide any evidence of trait overdispersion, for which the functional diversity in the mesohabitats with riparian forest can only be considered high in relation to the other mesohabitats. Likewise, the functional dispersion was lower than randomly expected across seasons, indicating trait underdispersion, as it has been observed in other rivers (Fitzgerald et al., 2017), while the lower functional richness during falling and low waters might signal a reduction in niches during the dry seasons.

In conclusion, the results suggest a significant influence of the substrate type, the presence of riparian forest, the current velocity and the seasonality in the organisation of the fish assemblages in the mesohabitats of the River Kakada. The proximity of the riparian forests propitiates a higher substrate structural complexity and a wider offer of trophic resources, all of which facilitate the coexistence of a high diversity of fish species with higher diversity of traits in comparison to sandy bottoms and rocky substrates. In the latter, the current velocity might be acting as a filter that limits the diversity of traits and species that can thrive in rocky substrates and constrains the assemblages' functional space. Nevertheless, the trait underdispersion in the fish assemblages of the four mesohabitats suggests potential habitat filtering in all of them (Southwood, 1977; Keddy, 1992; Townsend \& Hildrew, 1994). The seasonality, on the other hand, generates variations in species composition and diversity across the hydrological cycle, probably through processes of colonisation and dispersion, as proposed in the patch dynamics model (Townsend, 1989; Winemiller et al., 2010). The random functional richness during rising and high waters would indicate stochas- tic colonisation processes during floods. However, the seasonal replacement of functionally similar species suggests temporal segregation in order to avoid interspecific competition (Coleman \& Hynes, 1970). Consequently, the assembly of fish communities in the mesohabitats of the River Kakada is likely driven by a combination of environmental and biotic factors, as well as by stochastic processes.

Through this research, a description of the spatiotemporal patterns of the fish taxonomic diversities in mesohabitats of the River Kakada is provided. However, it should be made clear that this study is not a comprehensive inventory of the fish fauna in this river. Due to the fishing methods applied, the fish species inhabiting in deeper areas of the river could not be sampled, including the very abundant Serrasalmus rhombeus (Linnaeus, 1766), Ageneiosus inermis (Linnaeus, 1766) and Doras carinatus (Linnaeus, 1766). Despite these limitations, the results provide baseline information that might serve as a reference for future studies that measure the effects of gold mining in the upper River Caura Basin. The advantage of the framework used in this research lays in the easy and inexpensive sampling methods, conditions that are important in the design of studies encompassing the assessment of river integrity.

Gold mining activities have produced changes in taxonomic and functional composition in streams of the Guiana Shield, altering the structure of the fish assemblages through decreases in the abundances of habitat-specialist species in favour of habitat-generalist species (Brosse et al., 2011). These activities might severely threat the fish assemblages in the rocky substrates of the River Kakada, which are unique within the River Caura basin (Machado-Allison et al., 2003), since the deforestation and habitat degradation facilitate the sedimentation of channels, burying the rocky substrates and causing a reduction in the water flow (Ribeiro et al., 2016). Furthermore, the deforestation of the riparian forests for the settling of gold mines might decrease the fisheries productivity for indigenous peoples Yekwana and Sanema that live in the upper River Caura basin, since the presence of riparian forests is directly associated to fish abundance and biomass (Arantes et al., 2018) as well as to catch per unit effort (Castello et al., 2018). The measure of establishing the River Caura Basin under the figure of national park alone might not be enough to protect the ichthyofauna of the River Kakada and other rivers and streams within this basin. It is necessary to monitor the park to prevent the settling of new mines, and to dismantle the existing ones. Additionally, considering the vast extension and fish diversity within this park, 
more studies are necessary, particularly in the upper basin, to fully characterise the fish communities.

\section{Conclusions}

In broad terms, fishes in the Guiana Shield have evolved under particular conditions that involve rocky substrates, dense riparian forests and highly transparent waters with low conductivities. These conditions also exert an influence on the assembly processes of fishes. The fish assemblages in the mesohabitats of the River Kakada exhibit high taxonomic and functional diversities. Fish composition and abundances varied significantly across seasons, implying that the fish assembly is subjected to stochastic events. This taxonomic turnover, however, was not accompanied by functional turnover, indicating temporal segregation among functionally similar species that might be a response of the species to avoid interspecific competition. At the same time, the presence of riparian forest seems to favour higher taxonomic and functional diversity in the littorals of the river, in comparison to rapids or sandy bottoms with open waters. Nevertheless, all mesohabitats showed lower functional dispersion than randomly expected, which suggests environmental filters exert an influence on the organisation of fish assemblages in all of them. These results have important implications if we consider that the environmental conditions of the River Kakada might be greatly modified by the presence of gold mines. Our results highlight the importance of habitat conditions at a local scale and of temporal dynamics in the assembly of freshwater fish in rivers of the Guiana Shield and suggest interplay among environmental filters, biotic and stochastic processes as mechanisms of assembly within mesohabitats of these rivers.

\section{References}

Abrams P. 1983. The theory of limiting similarity. Annual Review of Ecology and Systematics 14: 359-376.

Anderson M.J. 2001. A new method for non-parametric multivariate analysis of variance. Austral Ecology 26(1): 32-46. DOI: 10.1111/j.1442-9993.2001.01070.pp.x

Anderson M.J., Gorley R.N., Clarke K.R. 2008. PERMANO$V A+$ for PRIMER: Guide to Software and Statistical Methods. Plymouth, UK: Primer-EB Ltd. 214 p.

Arantes C.C., Winemiller K.O., Petrere M., Castello L., Hess L.L., Freitas C.E.C. 2018. Relationships between forest cover and fish diversity in the Amazon River floodplain. Journal of Applied Ecology 55(1): 386-395. DOI: 10.1111/1365-2664.12967

Armbruster J.W. 2002. The species of Hypostomus cochliodon group (Siluriformes: Loricariidae). Zootaxa 249(1): 1-60. DOI: 10.11646/zootaxa.249.1.1
Arrington D.A., Winemiller K.O. 2006. Habitat affinity, the seasonal flood pulse, and community assembly in the littoral zone of a Neotropical floodplain river. Journal of the North American Benthological Society 25(1): 126-141. DOI: 10.1899/0887-3593(2006)25[126:HATSFP]2.0.CO;2

Arrington D.A., Winemiller K.O., Layman C.A. 2005. Community assembly at the patch scale in a species rich tropical river. Oecologia 144(1): 157-167. DOI: 10.1007/s00442-005-0014-7

Brosse S., Grenouillet G., Gevrey M., Khazraie K., Tudesque L. 2011. Small-scale gold mining erodes fish assemblage structure in small neotropical streams. Biodiversity and Conservation 20(5): 1013-1026. DOI: 10.1007/ s10531-011-0011-6

Casatti L., Castro R.M.C. 2006. Testing the ecomorphological hypothesis in a headwater riffles fish assemblage of the rio São Francisco, southeastern Brazil. Neotropical Ichthyology 4(2): 203-214. DOI: 10.1590/S167962252006000200006

Castello L., Hess L.L., Thapa R., McGrath D.G., Arantes C.C., Renó V.F., Isaac V.J. 2018. Fishery yields vary with land cover on the Amazon River floodplain. Fish and Fisheries 19(3): 431-440. DOI: 10.1111/faf.12261

Chao A., Jost L. 2012. Coverage-based rarefaction and extrapolation: standardizing samples by completeness rather than size. Ecology 93(12): 2533-2547. DOI: 10.1890/11-1952.1

Chao A., Gotelli N., Hsieh T.C., Sander E., Ma K.H., Colwell R.K., Ellison A. 2014. Rarefaction and extrapolation with Hill numbers: a framework for sampling and estimation in species diversity studies. Ecological Monographs 84(1): 45-67. DOI: 10.1890/13-0133.1

Chernoff B., Machado-Allison A. 1999. Bryconops colaroja and $B$. colanegra, two new species from the Cuyuní and Caroní drainages of South America (Teleostei: Characiformes). Ichthyological Explorations of Freshwaters 10(4): 355-370.

Chernoff B., Machado-Allison A., Provenzano F., Willink P.W., Petry P. 2002. Bryconops imitator, a new species from the Río Caura basin of Venezuela (Teleostei: Characiformes). Ichthyological Explorations of Freshwaters 13(3): 193-202.

Chernoff B., Machado-Allison A., Willink P.W., ProvenzanoRizzi F., Petry P., García, J.V., Pereira G., Rosales J., Bevilacqua M., Díaz W. 2003. The Distribution of Fishes and Patterns of Biodiversity in the Caura River Basin, Bolívar State, Venezuela. In: B. Chernoff, A. MachadoAllison, K. Riseng, J.R. Montambault (Eds.): A Biological Assessment of the Aquatic Ecosystems of the Caura River Basin, Bolivar State, Venezuela. RAP Bulletin of Biological Assessment 28. Washington DC: Conservation International Center for Applied Biodiversity Science Department of Conservation Biology. P. 86-96.

Cilleros K., Allard L., Vigouroux R., Brosse S. 2017. Disentangling spatial and environmental determinants of fish species richness and assemblage structure in Neotropical rainforest streams. Freshwater Biology 62(10): 1-14. DOI: $10.1111 /$ fwb. 12981

Clarke K.R., Gorley R.N. 2006. PRIMER v6: User Manual/ Tutorial. Plymouth UK. Primer-EB Ltd. 129 p. 
Cochran-Biederman J.L., Winemiller K.O. 2010. Relationships among habitat, ecomorphology and diets of cichlids in the Bladen River, Belize. Environmental Biology of Fishes 88(2): 143-152. DOI: .1007/s10641-010-9624-y

Coleman M.J., Hynes H.B.N. 1970. The life histories of some Plecoptera and Ephemeroptera in a southern Ontario stream. Canadian Journal of Zoology 48(6): 1333-1339. DOI: 10.1139/z70-227

Díaz-Pérez W., Daza F., Sarmiento W. 2012. Composición florística, estructura y diversidad del bosque ribereño del Río Kakada, Cuenca del Río Caura, estado Bolívar, Venezuela. Revista Cientifica UDO Agrícola 12(2): 275-289.

Echevarría G., González N. 2017. Co-occurrence patterns of fish communities in littorals of three floodplain lakes of the Orinoco River, Venezuela. Journal of Threatened Taxa 9(6): 10249-10260. DOI: 10.11609/ jott.2710.9.6.10249-10260

Echevarría G., González N. 2018. Fish trait diversity in littorals of two floodplain lakes of the highly biodiverse Caura River, Venezuela. Ecology of Freshwater Fish 27(1): 158-169. DOI: .1111/eff.12333

Echevarría G., Gonzalez N., Mass F. 2011. Aspectos reproductivos de la comunidad de peces de la cuenca alta del río Caura, Venezuela. Ciencia 19(1): 25-40.

Echevarría G., Rodríguez J.P., Machado-Allison A. 2017. Seasonal fluctuations in taxonomic and functional diversity in assemblages of catfishes in the Venezuelan Arauca River Floodplain. Studies on Neotropical Fauna and Environment 53(1): 38-53. DOI: 10.1080/01650521.2017.1387426

Fitzgerald D.B., Winemiller K.O., Sabaj Pérez M.H., Sousa L.M. 2017. Seasonal changes in the assembly mechanisms structuring tropical fish communities. Ecology 98(1): 21-31. DOI: 10.1002/ecy.1616

Froese R., Pauly D. (Eds.). 2018. FishBase. World Wide Web electronic publication. Available from www.fishbase.org

Funk V.A., Kelloff C.L. 2009. Introduction. In: R.P. Vari, C.J. Ferraris, A. Radosavljevic, V.A. Funk (Eds.): Checklist of Freshwater Fishes of the Guiana Shield. Bulletin of the Biological Society of Washington 17: 1-8.

Géry J. 1977. Characoids of the world. Neptune City: T.F.H. Publications, Inc. Ltd. 672 p.

González N., Vispo C. 2004. Ecología trófica de algunos peces importantes en lagunas de inundacion del bajo río Caura, Estado Bolívar, Venezuela. Memoria de la Fundación La Salle de Ciencias Naturales "2003": 147-183.

González N., Echevarría G., Daza F., Mass F. 2012a. List Illustrated list of additions to the ichthyofauna of the Caura River, Venezuela. Check List 8(1): 43-52. DOI: 10.15560/8.1.043

González N., Lasso C., Rosales J. 2012b. Estructura trófica de las comunidades de peces durante un ciclo hidrológico en dos lagunas inundables de la cuenca del bajo Río Orinoco. Memoria de la fundacion La Salle de Ciencias Naturales 173: 39-70.

Hsieh T.C., Ma K.H., Chao A. 2016. iNEXT: interpolation and Extrapolation for species diversity. $R$ package version 2.0.12. Available from http://chao.stat.nthu.edu.tw/ blog/software-download/
Gotelli N.J. 2000. Null Model Analysis of Species Co-Occurrence Patterns. Ecology 81(9): 2606-2621. DOI: 10.1890/0012-9658(2000)081[2606:NMAOSC]2.0.CO;2

Jost L. 2006. Entropy and diversity. Oikos 113(2): 363-375. DOI: $10.1111 / \mathrm{j} .2006 .0030-1299.14714 . \mathrm{x}$

Junk W., Bayley P., Sparks E. 1989. The Flood Pulse Concept in River - Floodplain Systems. In: P. Dodge (Ed.): Proceedings of the International Large Rivers Simposium. Canadian Special Publications in Fish and Aquatic Science 106. Ontario. P. 110-127.

Keddy P. 1992. Assembly and response rules: two goals for predictive community ecology. Journal of Vegetation Science 3(2): 157-164. DOI: 10.2307/3235676

Kembel S.W., Cowan P.D., Helmus M.R., Cornwell W.K., Morlon H., Ackerly D.D., Blomberg S.P., Webb C.O. 2010. Picante: R tools for integrating phylogenies and ecology. Bioinformatics 26(11): 1463-1464. DOI: 10.1093/bioinformatics/btq166

Kullander S., Royero R., Taphorn D.C. 1992. Two new species of Geophagus (Teleostei: Cichlidae) from the Río Orinoco drainage in Venezuela. Ichthyological Exploration of Freshwaters 3(4): 359-375.

Laliberté E., Legendre P. 2010. A distance-based framework for measuring functional diversity from multiple traits. Ecology 91(1): 299-305. DOI: 10.1890/08-2244.1

Laliberté A.E., Shipley B., Laliberté M.E. 2014. FD: measuring functional diversity from multiple traits, and other tools for functional ecology. R package version 1.0-12. $27 \mathrm{p}$.

Lasso C., Provenzano F. 1997. Chaetostoma vasquezi, nueva especie de corroncho del Escudo de Guayana, estado Bolívar, Venezuela (Siluroidei: Loricariidae) descripción y consideraciones biogeográficas. Memorias de la Sociedad de Ciencias Naturales La Salle 57(147): 53-65.

Lasso C., Machado-Allison A. 2000. Sinopsis de las especies de peces de la familia Cichlidae presentes en la cuenca del río Orinoco: claves, diagnosis, aspectos bio-ecológicos e ilustraciones. Caracas: Universidad Central de Venezuela, Facultad de Ciencias, Instituto de Zoología Tropical, Museo de Biología. 171 p.

López-Fernández H., Taphorn D.C., Kullander S.O. 2006. Two New Species of Guianacara from the Guiana Shield of Eastern Venezuela (Perciformes: Cichlidae). Copeia 2006(3): 384-395. DOI: 10.1643/0045-8511(2006)2006[384:TNSOGF]2.0.CO;2

López-Fernández H., Arbour J., Willis S., Watkins C., Honeycutt R.L., Winemiller K.O. 2014. Morphology and efficiency of a specialized foraging behavior, sediment sifting, in neotropical cichlid fishes. PLoS ONE 9(3): e89832. DOI: 10.1371/journal.pone.0089832

Lujan N.K., Winemiller K.O., Armbruster J.W. 2012. Trophic diversity in the evolution and community assembly of loricariid catfishes. BMC Evolutionary Biology 12(1): 124. DOI: 10.1186/1471-2148-12-124

Machado-Allison A., Kullander S.O., Lasso C.A. 1989. Description of a new Apistogramma species (TeleosteiCichlidae) from the Morichal River Slong in Venezuela. Acta Biologica Venezuelica 12(3-4): 131-139.

Machado-Allison A., Chernoff B., Buckup P.A. 1996. Bryconops humeralis y $B$. vibex, dos nuevas especies del 
genero Bryconops Kner (1858) para Venezuela. Acta Biologica Venezuelica 16(2): 43-58.

Machado-Allison A., Chernoff B., Provenzano F.R., Willink P.W., Marcano A., Petry P., Sidlaukas B., Jones T. 2003. Inventory, Relative Abundance and Importance of Fishes in the Caura River Basin, Bolívar State, Venezuela. In: B. Chernoff, A. Machado-Allison, K. Riseng, J. Montambault (Eds.): A Biological Assessment of the Aquatic Ecosystems of the Caura River Basin, Bolivar State, Venezuela. Washington DC.: Conservation International Center for Applied Biodiversity Science Department of Conservation Biology. P. 64-74.

Mago-Leccia F. 1994. Electric fishes of the continental waters of America. Vol. 29. Caracas: Fundación para el Desarrollo de las Ciencias Físicas, Matemáticas y Naturales. $226 \mathrm{p}$.

Mason N.W.H., Mouillot D., Lee W.G., Wilson J.B. 2005. Functional richness, functional and functional evenness divergence: the primary of functional components diversity. Oikos 111(1): 112-118. DOI: 10.1111/j.00301299.2005.13886.x

Mason N.W.H., Lanoiselée C., Mouillot D., Wilson J.B., Argillier C. 2008. Does niche overlap control relative abundance in French lacustrine fish communities? A new method incorporating functional traits. Journal of Animal Ecology 77(4): 661-669. DOI: 10.1111/j.13652656.2008.01379.x

Ministerio del Poder Popular para el Ambiente. 2007. Análisis ecológico social y ordenamiento territorial de la región del río Caura. Base técnica. Caracas: Ministerio para el poder popular para el Ambiente. Despacho de la Viceministra de ordenación y administración ambiental. 241 p.

Mouillot D., Graham N., Villéger S., Mason N.W.H., Bellwood D.R. 2013. A functional approach reveals community responses to disturbances. Trends in Ecology \& Evolution 28(3): 167-177. DOI: 10.1016/j.tree.2012.10.004

Nijssen H., Isbrücker I.J. 1982. Corydoras boehlkei, a new catfish from the Río Caura system in Venezuela (Pisces, Siluriformes, Callichthyidae). Proceedings of the Academy of Natural Science of Philadelphia 134: 139-142.

Oyakawa O.T., Mattox G.M.T. 2009. Revision of the Neotropical trahiras of the Hoplias lacerdae species-group (Ostariophysi: Characiformes: Erythrinidae) with descriptions of two new species. Neotropical Ichthyology 7(2): 117-140. DOI: 10.1590/S1679-62252009000200001

Pease A.A., González-Díaz A.A., Rodiles-Hernández R., Winemiller K.O. 2012. Functional diversity and traitenvironment relationships of stream fish assemblages in a large tropical catchment. Freshwater Biology 57(5): 1060-1075. DOI: 10.1111/j.1365-2427.2012.02768.x

Poff N. 1997. Landscape filters and species traits: towards mechanistic understanding and prediction in stream ecology. Journal of the North American Benthological Society 16(2): 391-409. DOI: 10.2307/1468026

Presidencia de la República Bolivariana de Venezuela. 2016. Decreto No 2.231, mediante el cual se autoriza la creación de una Empresa del Estado, bajo la forma de Compañia Anónima, que se denominará Compañia Anónima Militar de Industrias Mineras, Petrolíferas y de Gas (CAMIMPEG). Caracas. Gaceta Oficial 40.845. P. 426327-426330.

Presidencia de la República Bolivariana de Venezuela. 2017. Decreto No. 2.767. Creación del Parque Nacional Caura. Caracas. Gaceta Oficial 41.118. P. 434.575-434.578.

R Development Core Team. 2012. R: A language and environment for statistical computing. Vienna, Austria. Available from http://www.R-project.org/

Ribeiro M.D., Teresa F.B., Casatti L. 2016. Use of functional traits to assess changes in stream fish assemblages across a habitat gradient. Neotropical Ichthyology 14(1): e140185. DOI: 10.1590/1982-0224-20140185

Riseng K., Sparks J. 2003. A Limnological Analysis of the Caura River Basin, Bolívar State, Venezuela. RAP Bulletin of Biological Assessment 28. In: B. Chernoff, A. MachadoAllison, K. Riseng, J. Montambault (Eds.): A Biological Assessment of the Aquatic Ecosystems of the Caura River Basin, Bolivar State, Venezuela. Washington DC.: Conservation International Center for Applied Biodiversity Science Department of Conservation Biology. P. 44-48.

Rodríguez M., Lewis W.M. Jr. 1997. Structure of fish assemblages along environmental gradients in floodplain lakes of the Orinoco River. Ecological Monographs 67(1): 109-128.DOI:10.1890/0012-9615(1997)067[0109:SOFAAE]2.0.CO;2

Rodrigues-Filho C.A.S., Gurgel-Lourenço R.C., Lima S.M.Q., de Oliveira E.F., Sánchez-Botero J.I. 2017. What governs the functional diversity patterns of fishes in the headwater streams of the humid forest enclaves: environmental conditions, taxonomic diversity or biotic interactions? Environmental Biology of Fishes 100(9): 1023-1032. DOI: 10.1007/s10641-017-0603-4

Southwood T. 1977. Habitat, the templet for ecological strategies? Journal of Animal Ecology 46: 337-365.

Taphorn D. 1992. The characiform fishes of the Apure River drainage. Biollania 4: 1-537.

Teresa F.B., Casatti L. 2012. Influence of forest cover and mesohabitat types on functional and taxonomic diversity of fish communities in Neotropical lowland streams. Ecology of Freshwater Fish 21(3): 433-442. DOI: 10.1111/j.1600-0633.2012.00562.x

Thorp J., Thoms M., Delong M. 2008. The Riverine Ecosystem Synthesis. London, UK: Elsevier. 233 p.

Townsend C.R. 1989. The patch dynamics concept of stream community ecology. Journal of the North American Benthological Society 8(1): 36-50. DOI: 10.2307/1467400

Townsend C., Hildrew A. 1994. Species traits in relation to a habitat templet for river systems. Freshwater Biology 31(3): 265-275. DOI: 10.1111/j.13652427.1994.tb01740.x

Vari R.P. 1989. Systematics of the Neotropical characiform genus Psectrogaster Eigenmann and Eigenmann (Pisces: Characiformes). Smithsonian Contributions to Zoology 481: 1-43. DOI: 10.5479/si.00810282.481

Vari R.P. 1983. Phylogenetic relationships of the families Curimatidae, Prochilodontidae, Anostomidae, and Chilodontidae (Pisces, Characiformes). Smithsonian Contributions to Zoology 378: 1-60. DOI: 10.5479/ si.00810282.378 
Vari R.P., Ferraris C.J. 2009. Fishes of the Guiana Shield. In: R.P. Vari, C.J. Ferraris, A. Radosavljevic, V.A. Funk (Eds.): Checklist of Freshwater Fishes of the Guiana Shield. Bulletin of the Biological Society of Washington 17: 9-20.

Vari R.P., Ferraris C.J. 2013. Two New Species of the Catfish Genus Tatia (Siluriformes: Auchenipteridae) from the Guiana Shield and a Reevaluation of the Limits of the Genus. Copeia 2013(3): 396-402. DOI: 10.1643/CI-12-115

Villéger S., Mason N.W.H., Mouillot D. 2008. New multidimensional functional diversity indices for a multifaceted framework in functional ecology. Ecology 89(8): 290-301. DOI: 10.1890/07-1206.1

Villéger S., Brosse S. Mouchet M., Mouillot D., Vanni M.J. 2017. Functional ecology of fish: current approaches and future challenges. Aquatic Sciences 79(4): 783 801. DOI: $10.1007 / \mathrm{s} 00027-017-0546-\mathrm{z}$

Vispo C., Lasso C.A., Lasso-Alcalá Ó.M., González N. 2003. Geographical and temporal variation in fish communities of the floodplain lakes of the lower Caura drainage in the Venezuelan Guayana. Scientia Guaianae 12: 297-327.
Weiher E., Keddy P. 2004. Assembly rules as general constraints on community composition. In: E. Weiher, P. Keddy (Eds.): Ecological Assembly Rules. Perspectives, Advances, Retreats. Cambridge, UK: Cambridge University Press. P. 251-271.

Willink P.W., Chernoff B., Machado-Allison A., Provenzano F., Petry P. 2003. Aphyocharax yekwanae, a new species of bloodfin tetra (Teleostei: Characiformes: Characidae) from the Guyana Shield of Venezuela. Ichthyoplogical Explorations of Freshwaters 14(1): 1-8.

Willis S.C., Winemiller K.O., Lopez-Fernandez H. 2005. Habitat structural complexity and morphological diversity of fish assemblages in a Neotropical floodplain river. Oecologia 142(2): 284-295. DOI: 10.1007/s00442-004-1723-z

Winemiller K.O. 1991. Ecomorphological diversification in lowland freshwater fish assemblages from five biotic regions. Ecological Monographs 61(4): 343-365. DOI: $10.2307 / 2937046$

Winemiller K.O., Flecker A.S., Hoeinghaus D.J. 2010. Patch dynamics and environmental heterogeneity in lotic ecosystems. Journal of the North American Benthological Society 29(1): 84-99. DOI: 10.1899/08-048.1

\title{
ТАКСОНОМИЧЕСКОЕ И ФУНКЦИОНАЛЬНОЕ РАЗНООБРАЗИЕ РЫБ В МЕСТООБИТАНИЯХ Р. КАКАДА НАЦИОНАЛЬНОГО ПАРКА «КАУРА» (ВЕНЕСУЭЛА)
}

\author{
Г. Эчеварриа ${ }^{1}$, Н. Гонсалез ${ }^{2}$ \\ ${ }^{1}$ Институт научных исследований Венесуэль, Венесуэла \\ e-mail:hydropsichidae@gmail.com \\ ${ }^{2}$ Фонд естественных наук Ла Салле, Венесуэла \\ e-mail:nirsongonz@gmail.com
}

Национальный парк «Каура» охватывает весь бассейн реки Каура, одной из гидрографический систем с наиболее богатым биоразнообразием в Венесуэле. Однако ихтиофауна, особенно в верхней части бассейна, слабо изучена. В настоящем исследовании описано таксономическое и функциональное разнообразие рыб в местообитаниях реки Какада, главного притока р. Кауры в верхнем ее течении (Южная Венесуэла). Рыбы были отобраны в четырех типах местообитаний с помощью неводов в течение четырех различных периодов, представляя гидрологические сезоны повышения уровня воды, высокого уровня воды, убыли воды и низкого уровня воды. Индексы функционального разнообразия были рассчитаны на основе четырех признаков: размер, трофическое сообщество, ориентация рта и форма тела. Всего 56 видов рыб было зарегистрировано. Были отмечены значительные различия в видовом составе сообществ рыб и их таксономических различиях среди местообитаний и гидрологических сезонов. В то же время таксономическое и функциональное разнообразие были выше в местообитаниях, представленных прибрежными лесами. Однако сезонные колебания функционального состава или функционального разнообразия не были отмечены. Каменистые субстраты характеризовались уникальными комплексами видов, приуроченными к определенным местообитаниям и характеризующимися определенным набором признаков. С другой стороны, наличие прибрежного леса и более структурно сложных субстратов благоприятствует сосуществованию большого разнообразия рыб с различными комбинациями признаков, тогда как сезонные колебания уровня воды могут усугублять стохастические процессы распространения и колонизации, которые порождают колебания видового состава и таксономического разнообразия. Учитывая распространение кустарных золотых приисков в Национальном парке «Каура», результаты настоящей работы могут послужить справочной информацией для будущих исследований по оценке последствий деятельности золотодобывающих приисков на целостность реки и рыбных сообществ.

Ключевые слова: Гвианское плоскогорье, прибрежный пойменный лес, признаки рыб, сезонные особенности разнообразия, структура сообществ рыб 